\title{
CORONAVIRUS
}

\section{A broadly cross-reactive antibody neutralizes and protects against sarbecovirus challenge in mice}

\author{
David R. Martinez ${ }^{1 \dagger}$, Alexandra Schäfer ${ }^{1} \uparrow$, Sophie Gobeil ${ }^{2 \dagger}$, Dapeng Li ${ }^{2} \uparrow$, Gabriela De la Cruz ${ }^{3}$, Robert Parks ${ }^{2}$, \\ Xiaozhi Lu ${ }^{2}$, Maggie Barr ${ }^{2}$, Victoria Stalls ${ }^{2}$, Katarzyna Janowska ${ }^{2}$, Esther Beaudoin ${ }^{2}$, Kartik Manne ${ }^{2}$, \\ Katayoun Mansouri ${ }^{2}$, Robert J. Edwards ${ }^{2}$, Kenneth Cronin ${ }^{2}$, Boyd Yount ${ }^{1}$, Kara Anasti ${ }^{2}$, Stephanie A. \\ Montgomery $^{4}$, Juanjie Tang ${ }^{5}$, Hana Golding ${ }^{5}$, Shaunna Shen ${ }^{7}$, Tongqing Zhou ${ }^{6}$, Peter D. Kwong ${ }^{6}$, Barney S. \\ Graham $^{6}$, John R. Mascola ${ }^{6}$, David. C. Montefiori ${ }^{7}$, S. Munir Alam ${ }^{2}$, Gregory D. Sempowski ${ }^{2}$, Surender \\ Khurana $^{5}$, Kevin Wiehe ${ }^{2}$, Kevin O. Saunders ${ }^{2,7}$, Priyamvada Acharya ${ }^{2,7^{*}}$, Barton F. Haynes ${ }^{2 *}$, Ralph S. Baric ${ }^{{ }^{*}}$ \\ ${ }^{1}$ Department of Epidemiology, University of North Carolina at Chapel Hill, Chapel Hill, NC, USA 2 Duke Human Vaccine Institute, Duke University School of Medicine, \\ Durham, NC, USA ${ }^{3}$ Lineberger Comprehensive Cancer Center, University of North Carolina School of Medicine, Chapel Hill, NC, USA ${ }^{4}$ Department of Laboratory Medicine \\ and Pathology, University of North Carolina School of Medicine, Chapel Hill, NC, USA ${ }^{5}$ Division of Viral Products, Center for Biologics Evaluation and Research (CBER), FDA, \\ Silver Spring, Maryland, USA, 20871. ${ }^{6}$ Vaccine Research Center, National Institute of Allergy and Infectious Diseases, NIH, Bethesda, MD, USA ${ }^{7}$ Department of Surgery, \\ Duke University School of Medicine, Durham, NC, USA \\ †These authors contributed equally. \\ *Corresponding author. Email: Priyamvada Acharya, P.A., priyamvada.acharya@duke.edu Barton F. Haynes, B.F.H., barton.haynes@duke.edu Ralph S. Baric, R.S.B., \\ rbaric@email.unc.edu
}

Severe acute respiratory syndrome coronaviruses 1 (SARS-CoV) and 2 (SARS-CoV-2), including SARS-CoV2 variants of concern, can cause deadly infections. The mortality associated with sarbecovirus infection underscores the importance of developing broadly effective countermeasures against them, which could be key in the prevention and mitigation of current and future zoonotic events. Here, we demonstrate the neutralization of SARS-CoV, bat coronaviruses WIV-1, RsSHC014, and SARS-CoV-2 variants D614G, B.1.1.7, B.1.351, P.1, B.1.429, B.1.526, B.1.617.1, and B.1.617.2 by a receptor-binding domain (RBD)-specific human antibody, DH1047. Prophylactic and therapeutic treatment with DH1047 was protective against SARS-CoV, WIV-1, RsSHC014, and SARS-CoV-2 B.1.351 infection in mice. Binding and structural analysis showed high affinity binding of $\mathrm{DH} 1047$ to an epitope that is highly conserved among sarbecoviruses. Thus, $\mathrm{DH} 1047$ is a broadly protective antibody that can prevent infection and mitigate outbreaks caused by SARS-related strains and SARS-CoV-2 variants. Our results also suggest that the conserved RBD epitope bound by $\mathrm{DH} 1047$ is a rational target for a universal sarbecovirus vaccine.

\section{INTRODUCTION}

The emergence of severe acute respiratory syndrome coronavirus (SARS-CoV) in 2003 led to more than 8,000 infections and 800 deaths $(1,2)$. In 2019, SARS-CoV-2 emerged in Wuhan, China (3). The spread of SARS-CoV-2, the virus that causes coronavirus disease 2019 (COVID-19) was rapid. By March 2020, the World Health Organization (WHO) had declared the SARS-CoV-2 outbreak a global pandemic. By October 2021, more than 200 million people had been infected globally, resulting in over 4.5 million deaths. This was associated with the documented emergence of several SARS-CoV-2 variants which can partially evade host immunity. Therefore, there is a need to develop safe and effective broad-spectrum countermeasures that can prevent the rapid spread and attenuate the severe disease outcomes associated with current and future SARS-related virus emergence events.

Highly pathogenic coronavirus outbreaks in humans are likely of bat origin (4), and there is great genetic diversity among bat SARS-related viruses (5). Zoonotic coronaviruses of bat origin, such as RsSHC014 and WIV-1, can utilize the human angiotensin converting enzyme 2 (ACE2) receptor for cell entry and can infect human airway cells $(6,7)$, highlighting their potential for emergence in naïve human populations. Moreover, existing therapeutic monoclonal antibodies against SARS-CoV, and SARS-CoV-2 mRNA vaccines do not fully protect against zoonotic SARS-related virus infection in vivo (6-8). Given the pandemic potential of SARS-related viruses, the development of broadly effective countermeasures, such as universal vaccination strategies (8-10) and coronavirus cross-reactive monoclonal antibodies, is a global health priority. Moreover, given the emergence of the SARS-CoV-2 variants that are partially or fully resistant to some neutralizing antibodies authorized for COVID-19 treatment (11-13), there is a need to develop mAb therapies that are broadly effective against existing SARS-CoV-2 variants and zoonotic SARS-related viruses that may emerge in the future. 
The receptor binding domain (RBD) of SARS-CoV-2 is one of the targets for highly potent neutralizing antibodies. Despite the high degree of genetic diversity within the RBD in SARS-related viruses (5), antibodies can be engineered to recognize diverse SARS-related viruses. Rappazzo et al. recently reported that an engineered RBD-directed antibody, ADG-2, neutralized SARS-related viruses and protected against SARS-CoV and wild type SARS-CoV-2 (14). Therefore, the $\mathrm{RBD}$ of sarbecoviruses contains conserved epitopes that are the target of broadly neutralizing antibodies. In agreement with the notion that the RBD contains a conserved epitope shared among SARS, SARS-related, SARS-CoV-2 and the variants, we have identified a coronavirus cross-reactive RBD protective antibody: DH1047 (15).

\section{RESULTS \\ The identification of broadly cross-binding and neu- tralizing antibodies}

We previously isolated 1737 monoclonal antibodies (mAbs) from a SARS-CoV convalescent patient 17 years following infection and from a SARS-CoV-2 convalescent patient 36 days post infection (15). From this large panel of mAbs previously described by Li et al. we focused on 50 cross-reactive antibodies that bound to SARS-CoV, SARS-CoV-2, and other human and animal coronavirus antigens from genetically distinct sarbecoviruses. Importantly, sarbecoviruses vary in their ability to utilize human ACE2 and exhibit substantial genetic diversity in their RBDs (Fig. 1A) (15). To examine if these 50 cross-neutralizing mAbs neutralized pandemic and zoonotic sarbecoviruses, we measured neutralizing activity against a mouse-adapted SARS-CoV-2 (MA) virus, SARS-CoV, bat CoV WIV-1, and bat CoV RsSHC014 using live viruses. We identified four broadly cross-reactive antibodies, DH1235, DH1073, DH1046, and DH1047 (Fig. 1B to E). We focused our analyses on these four antibodies, as they had broad neutralization. DH1235 neutralized SARS-CoV-2 2AA MA, SARS-CoV, and bat coronavirus WIV-1 with half-maximal inhibitory concentration $\left(\mathrm{IC}_{50}\right)$ of $0.122,0.0403$, and $0.060 \mu \mathrm{g} / \mathrm{ml}$, respectively (Fig. 1B and table S1). DH1073 neutralized SARS-CoV-2 2AA MA, SARS-CoV, bat coronaviruses WIV-1 and RsSHC014 with $\mathrm{IC}_{50}$ of $0.808,0.016,0.267$, and 1.32 $\mu \mathrm{g} / \mathrm{ml}$, respectively (Fig. 1C and table S1). DH1046 neutralized SARS-CoV-2 2AA MA, SARS-CoV, bat coronaviruses WIV-1 and RsSHC014 with $\mathrm{IC}_{50}$ of $2.85,0.103,0.425$, and $1.27 \mathrm{\mu g} / \mathrm{ml}$, respectively (Fig. 1D and table S1). DH1047 was the most potent, and neutralized SARS-CoV-2 2AA MA, SARS-CoV, bat coronaviruses WIV-1 and RsSHC014 with $\mathrm{IC}_{50}$ of 0.397, 0.028, 0.191 , and $0.200 \mu \mathrm{g} / \mathrm{ml}$, respectively (Fig. $1 \mathrm{E}$ and table S1). As our study goal was to characterize the protective efficacy of cross-reactive antibodies, we compared the neutralization activity of DH1047 to two other mAbs currently in clinical trials, the cross-reactive ADG-2 (Adagio Therapeutics Inc, Adimab) and the potent REGN 10933 (Regeneron Pharmaceuticals), against SARS-CoV-2 B.1.351, SARS-CoV urbani, and RsSHC014 (fig. S1). Notably, ADG-2 was engineered for increased potency whereas DH1047 was not (14). REGN 10933 had reduced neutralizing activity against SARS-CoV-2 B.1.351 compared to both ADG-2 and DH1047 (fig. S1). Like DH1047, ADG-2 effectively neutralized SARS-CoV urbani whereas REGN 10933 did not. Last, both ADG-2 and DH1047 neutralized RsSHC014 whereas REGN 10933 did not (fig. S1).

To focus our screen on the four broadly neutralizing mAbs, we measured binding responses for DH1235, DH1073, DH1046, and DH1047 against other zoonotic bat spike proteins including RaTG13-CoV, bat RsSHC014, and against the spike protein of Pangolin GXP4L-CoV. DH1235, DH1073, DH1046, and DH1047 mAbs showed strong binding to bat RaTG13-CoV, bat RsSHC014, and pangolin GXP4L-CoV spike proteins in addition to SARS-CoV and SARS-CoV-2 (Fig. 2A to D). DH1235, DH1073, DH1046, and DH1047 bound to SARS-CoV-2 RBD and did not bind to the SARS-CoV-2 NTD. Although DH1235, DH1073, DH1046, and DH1047 were crossreactive against epidemic, pandemic, and zoonotic sarbecovirus spike proteins, they did not bind to MERS-CoV, $\mathrm{Hu}-$ CoV OC43, HuCoV NL63, or HuCoV 229E spike proteins (fig. S2), suggesting these mAbs recognize a conserved epitope found only in Group 2B betacoronaviruses.

To examine if these cross-reactive mAbs shared any overlap in their epitopes, we examined their binding footprint by both negative stain electron microscopy (NSEM) and surface plasmon resonance (SPR). DH1047 had an overlap with DH1235 but not with DH1073 and had different angles of approach to the SARS-CoV-2 spike protein (fig. S3A to C). Moreover, from SPR competition experiments, DH1047, DH1046, and DH1235 were outcompeted by one another (fig. S3D), whereas DH1073 was not, indicating that DH1073 targets a distinct non-cross-competing epitope. As DH1047 was the most potent $\mathrm{mAb}$ out of the four cross-reactive mAbs in our screen, we also performed NSEM, and observed binding of DH1047 to the RBD of bat RsSHC014 and SARS-CoV spike ectodomains, with overall similar orientations as was observed for DH1047 binding to the SARS-CoV-2 spike ectodomain (fig. S4) (15). A 3.20 Å cryo-EM structure of DH1047 bound to the SARS-CoV spike protein showed three DH1047 Fab bound to each of the 3 RBD of the ectodomain in the "up" position (1 Fab:1 RBD ratio) (Fig. 2E, fig. S5, and table S2). DH1047 binding to the SARS-CoV RBD involved interactions between the antibody heavy-chain-complementarity-determining-region 3 (HCDR3) and residues 356 to 372 of the RBD, and of the light-chain-complementarity-determining-region 1 (LCDR1) and LCDR3 regions with the RBD region spanning residues 390 to 404 . The LCDR3 also interacted with receptor-binding motif (RBM) residues 488 to 492 . The angle of approach and footprint of DH1047 on the SARS-CoV RBD closely resembled that in the SARS-CoV-2 complex (15) with 
steric overlap predicted with ACE2 binding (Fig. 2E). These results demonstrate that DH1047 binds to SARS-CoV and SARS-CoV-2 spike ectodomains by involving homologous interactions (Fig. 2F), consistent with our analysis of RBD sequence variability that showed a high degree of convergence of the DH1047 epitope (Fig. 2F) (9), thereby defining an RBD conserved site of vulnerability in sarbecoviruses.

We also defined the binding affinity of DH1047 against epidemic and zoonotic spike proteins. We measured binding on and off rates against both SARS-CoV and RsSHC014-CoV spike proteins by SPR. DH1047 bound to the SARS-CoV and RsSCH014-CoV spike proteins with high affinity, association rates $\left(>8.60 \mathrm{X}^{4} 0^{4} \mathrm{M}^{-1} \mathrm{~s}^{-1}\right)$ and dissociation rates $\left(<1.0 \mathrm{X}^{-5} 0^{-5}\right.$ $\mathrm{s}^{-1}$ ) (fig. S6), demonstrating that DH1047 binds tightly to both the epidemic SARS-CoV and pre-emergent bat coronavirus spike proteins. Finally, DH1235, DH1073, DH1046, and DH1047 exhibited medium to long HCDR3 lengths and variable nucleotide somatic mutation rates in the heavy chain genes. DH1235, DH1073, and DH1046, had HCDR3 lengths of 21,15 , and 24 , and nucleotide somatic hypermutation $(\mathrm{SMH})$ rates of 1.7, 9.0, and 4.7, respectively (table S3). The most potent neutralizing antibody DH1047 had HCDR3 lengths and $\mathrm{SMH}$ rates of 24 and 8.05 , respectively (table S3).

The protective activity of DH1235, DH1073, DH1O46, and DH1O47 against SARS-CoV

To define the protective efficacy of these four cross-reactive and broadly neutralizing RBD-specific IgG bNAbs, we passively immunized aged mice with DH1235, DH1073, DH1046, DH1047 and a negative control influenza mAb, CH65 (16), at 10mg $/ \mathrm{kg} 12$ hours prior to infection with SARSCoV mouse-adapted passage 15 (MA15) and evaluated lung viral titer replication. Demonstrating a disconnect between in vitro and in vivo protection, neither DH1235, DH1073, nor DH1046 protected SARS-CoV MA15 challenge in mice and all had lung viral replication comparable to that of control mice (Fig. 3A). In contrast, prophylactic administration of DH1047 fully protected mice from lung viral titer replication (Fig. 3A). Given the prophylactic potential of DH1047, we sought to also evaluate its therapeutic potential in this mouse model. We treated mice with control mAb or DH1047 at $10 \mathrm{mg} / \mathrm{kg}$ either at 12 hours before or 12 hours post infection with SARS-CoV MA15 and monitored mice for signs of clinical disease, including weight loss and pulmonary function, which was measured by whole-body plethysmography (Buxco), through day 4 post infection (4dpi). In agreement with the earlier SARSCoV MA15 experiment, prophylactic treatment with DH1047 protected mice from weight loss through 4dpi (Fig. 3B) and lung viral replication (Fig. 3C). Similarly, DH1047 therapy at 12 hours post infection resulted in reduced lung viral titers (Fig. 3C and fig. S7) as well as the macroscopic lung damage measured by the lung discoloration score (Fig. 3D and fig. S7). We also evaluated if the prophylactic and therapeutic administration of DH1047 protected against lung pathology as measured by lung discoloration, which is a visual metric of gross lung damage taken at the time of the necropsy, microscopic evaluation as measured by an acute lung injury (ALI) scheme, and a diffuse alveolar damage (DAD) scheme. ALI and DAD, which are characterized by histopathologic changes including alveolar septal thickening, protein exudate in the airspace, hyaline membrane formation, and neutrophils in the interstitium or alveolar sacs, were both blindly evaluated by a board-certified veterinary pathologist blinded to the groups. The prophylactic administration of DH1047 resulted in complete protection from macroscopic lung discoloration (Fig. 3D) and microscopic lung pathology as measured by ALI (Fig. 3E and fig. S7) and DAD (Fig. 3F and fig. S7). In contrast to the prophylactic treatment condition, therapeutic administration of DH1047 did not reduce microscopic lung pathology compared to control mice as measured by ALI (Fig. 3E and fig. S7) and DAD (Fig. 3F and fig. S7) in this highly vulnerable model for SARS-CoV pathogenesis. The prophylactic and therapeutic administration of DH1047 prevented degradation of pulmonary function compared to controls (Fig. 3G). Finally, both the prophylactic and therapeutic administration of DH1047 resulted in complete survival of infected mice, whereas only $50 \%$ of control mice survived (Fig. $3 \mathrm{H})$. Thus, DH1047 can prevent SARS-CoV disease when administered prophylactically and has measurable therapeutic benefits in a highly susceptible aged mouse model.

DH1O47 has prophylactic and therapeutic activity against bat pre-emergent coronaviruses and neutralizes SARS-CoV-2 variants in vitro.

As DH1047 neutralized both WIV-1 and RsSHC014 (Fig. 1), we sought to define if DH1047 had prophylactic and therapeutic efficacy in mice against these pre-emergent bat coronaviruses. We administered DH1047 prophylactically 12 hours before infection and therapeutically 12 hours post infection at $10 \mathrm{mg} / \mathrm{kg}$ in mice infected with bat coronaviruses. Prophylactic administration of DH1047 completely protected mice from WIV-1 lung viral replication and reduced lung viral titers in therapeutically treated mice compared to control mice (Fig. 4A). Similarly, prophylactic administration of DH1047 completely protected mice from RsSHC014 lung viral replication and reduced viral replication to near undetectable concentrations in therapeutically treated mice (Fig. 4B). Although we previously demonstrated the prophylactic and therapeutic efficacy of DH1047 against the SARS-CoV-2 Wuhan isolate in cynomolgus macaques (15), which exhibit mild SARS-CoV-2 disease (17), it was not known if the mutations present in the newly emerging SARS-CoV-2 variants would ablate the neutralizing activity of DH1047. We therefore evaluated if DH1047 could neutralize the prevalent variants of concern using both pseudovirus and live virus neutralization assays. DH1047 neutralized all tested variants of concern 
including SARS-CoV-2 D614G, B.1.1.7 (Alpha), B.1.351 (Beta), P.1 (Gamma), B.1.429, B.1.526, B.1.617.1 (Kappa), and B.1.617.2 (Delta) (Fig. 4C and Fig. 4D). The pseudovirus 50\% neutralization assay $\left(\mathrm{PsVNA}_{50}\right.$ ) values against all the variants ranged between 0.1214 and $0.1609 \mu \mathrm{g} / \mathrm{ml}$, confirming broad neutralization of SARS-CoV-2 variants of concern by DH1047 (Fig. 4D). Live virus neutralization also demonstrated the broadly neutralizing activity of $\mathrm{DH} 1047$, with $\mathrm{IC}_{50}$ values against D614G, B.1.1.7, and B.1.351 measured at 0.059, 0.081, and $0.111 \mu \mathrm{g} / \mathrm{ml}$, respectively.

The prophylactic and therapeutic activity of DH1O47 against SARS-CoV-2 B.1.351 in mice

Given that the B.1.351 variant is more resistant to both vaccine-elicited neutralizing antibodies (11, 18), and completely ablates the neutralizing activity of the Eli Lilly therapeutic monoclonal antibody, LY-CoV555 (13), we also sought to evaluate if DH1047 had prophylactic or therapeutic efficacy against SARS-CoV-2 B.1.351 in mice. We again utilized a highly susceptible and vulnerable aged mouse model in the SARS-CoV-2 B.1.351 protection experiments. Consistent with the SARS-CoV, WIV-1, and RsSHC014 in vivo data, prophylactic administration of DH1047 mediated complete protection against severe weight loss following SARS-CoV-2 B.1.351 challenge in aged mice (Fig. 5A). In contrast, we did not observe differences in weight loss after the therapeutic administration of DH1047 as compared to controls (Fig. 5A). Mice prophylactically treated with DH1047 had undetectable SARS-CoV-2 B.1.351 lung viral replication (Fig. 5B) and were also completely protected from macroscopic lung pathology compared to controls (Fig. 5C). Therapeutic administration of DH1047 resulted in a reduction in lung viral titers compared to control (Fig. 5B). We also evaluated the microscopic lung pathology as measured by ALI (Fig. 5D) and DAD scoring (Fig. 5E) schemes in this susceptible aged model for SARS-CoV-2 B.1.351 pathogenesis. Prophylactic administration of DH1047 protected mice from lung histopathology as measured by ALI and DAD compared to control mice. Additionally, we observed a reduction in ALI by the therapeutic administration of DH1047 as measure by macroscopic lung pathology (Fig. 5C) and lung histopathology (Fig. 5D). Finally, there was no difference in mortality in the SARS-CoV-2 B.1.351 challenge model in the control and DH1047-treated mice (Fig. 5F). Therefore, DH1047 can prevent and treat SARS-CoV-2 infections with the B.1.351 variant of concern in vivo. To determine the concentration at which we observe breakthrough infection in vivo, we performed a dose de-escalation study and treated mice prophylactically at 10,5 , and $1 \mathrm{mg} / \mathrm{kg}$. We observed full protection in mice treated with the $10 \mathrm{mg} / \mathrm{kg}$ dose but not in mice treated with the $5 \mathrm{mg} / \mathrm{kg}$ dose, measured by weight loss and lung discoloration, despite full protection lung viral replication compared to control (Fig. 5G to I). In contrast, incomplete protection from weight loss, breakthrough viral lung replication, and lung pathology was observed at the $1 \mathrm{mg} / \mathrm{kg}$ prophylaxis dose of DH1047 (Fig. 5G to I).

\section{The structural comparison of DH1O47 to other anti-} bodies targeting the RBD

Comparing the DH1047 epitope with that of representative RBD-directed antibodies from Class 1, 2, 3 and 4 (19), we found that the DH1047 footprint overlapped with antibody C105 (Class 1) and CR3022 (Class 4) (Fig. 5J and fig. S8). The DH1047 footprint on the RBD showed similarity with $\mathrm{Ab}$ H014 (20) and overlapped with the footprint of other antibodies whose epitopes overlap with that of CR3022 (21-23). The classification of RBD-directed antibodies has recently been re-defined to include a larger set of antibodies and finer epitope binning (24). DH1047 classifies in the RBD-6 category in this new system based on overlap of its footprint with CR3022, proximity to RBD-2a antibodies (such as REGN10933), and its ability to compete with ACE2 binding (15). Interestingly, single domain antibodies, or nanobodies, that potently neutralize SARS-CoV-2 show a close overlap with the DH1047 VH domain (fig. S8). Nanobody VHH V shows the closest overlap with its elongated HCDR3 loop binding to a similar RBD region as the HCDR3 of DH1047. We performed alanine scanning mutagenesis of the DH1047 HCDR3 residues proximal to the RBD epitope (fig. S9). Mutating residue Trp100B to Ala did not alter its binding to the ectodomain of SARS-CoV-2 spike protein stabilized with the two prolines (S$2 \mathrm{P})$, consistent with the orientation of the Trp side chain away from the epitope. Similarly, mutating residues Ser100A and Ser100C to Ala did not alter binding. Ala mutants of residues Leu100G and Asp100F notably reduced DH1047 binding to the spike protein even though these residues did not directly contact the RBD, possibly by disrupting the conformation of the long HCDR3 loop. Mutagenesis of the LCDR3 similarly resulted in notable reduction in binding observed for Tyr91Ala and Arg96Ala substitutions, although neither of these residues directly contacted the RBD. Reduction in binding was also observed for Ala substitution of residue Leu94 where the Leu side chain occupied a hydrophobic pocket formed by the heavy chain residues Leu100G and Ile58, and RBD residue Val394.

The DH1047 epitope also overlaps with that of antibody ADG-2, which was previously shown to neutralize SARSrelated viruses and protecting against SARS-CoV and SARSCoV-2 (14). The approach angles of DH1047 and ADG-2 differ, with a rotation about the Fab longitudinal axis pivoting the ADG-2 antibody more toward the ACE2 binding region compared to DH1047 (fig. S10A and B). In contrast to ADG-2 which uses VH3-21 for its heavy chain and has a 17 amino acid long HCDR3, DH1047 uses VH1-46 and has a 24 amino acid long HCDR3 (table S3) (14). To compare the therapeutic efficacy of DH1047 against ADG-2, we performed a head-to- 
head comparison study. Aged mice were therapeutically treated with either DH1047, ADG-2, or CH65 control mAbs at $10 \mathrm{mg} / \mathrm{kg}$ at 6 hours post infection with SARS-CoV-2 B.1.351. Mice treated with either DH1047 or ADG-2 were completely protected from weight loss, lung viral replication, and lung damage compared to controls (fig. S10C), suggesting that DH1047 has similar in vivo therapeutic profiles to ADG-2, which is another potent cross-protective mAb (14).

\section{DISCUSSION}

The emergence of SARS-CoV and SARS-CoV-2 in the last two decades underscores a critical need to develop broadly effective countermeasures against sarbecoviruses. Moreover, with the recent emergence of the more transmissible (25), modestly more virulent (26) B.1.1.7 variant (Alpha), B.1.351 (Beta), B.1.1.28 (Gamma), and the highly transmissible B.1.617.2 variant (Delta), all of which can partially evade existing countermeasures $(11,13,27)$, there is a need to develop next-generation mAb therapeutics that can broadly neutralize these variants, as well as future variants of concern. For example, the SARS-CoV-2 B.1.351 variant completely ablates the neutralization activity of the mAb LY-CoV555 $(13,28)$. As a result, the emergency use authorization (EUA) of LYCoV555 was recently rescinded by the U.S. Food and Drug Administration (FDA). In addition, the presence of the E484K mutation in many variants of concern, severely dampens the neutralization activity by more than 6-fold of the AstraZeneca COV2-2196 mAb, Brii BioSciences Brii-198 mAb, and the Regeneron REGN $10933 \mathrm{mAb}(11,28)$. In addition to evading currently monoclonal antibody therapeutics, some of the variants including B.1.351 can diminish the efficacy of clinically approved vaccines, including the Johnson \& Johnson singledose vaccine and the AstraZeneca ChAdOx1 $\mathrm{nCoV}-19$ vaccine $(29,30)$. Furthermore, some monoclonal antibodies isolated from vaccine recipients of the Moderna mRNA-1273 and Pfizer/BioNTech BNT162b2 vaccines also demonstrated reduced efficacy against mutations present in the variants (31). Therefore, current vaccine and $\mathrm{mAb}$ therapies must be monitored in real time to define the performance of existing therapies against newly emerging and spreading variants. In the setting of reduced vaccine efficacy, the deployment of $\mathrm{mAb}$ therapies that are effective against variants, such as DH1047, could be a strategy to help control the COVID-19 pandemic.

The development of universal vaccination strategies against sarbecoviruses will be improved by the identification and characterization of broadly protective and conserved epitopes across SARS-related virus strains. Several SARSrelated cross-reactive antibodies were recently described. For example, RBD-specific antibody, S2X259, neutralized SARS$\mathrm{CoV}-2$ variants and zoonotic SARS-related viruses, as measured by pseudovirus neutralization (32) and another RBDspecific antibody had broad protection against the SARSCoV-2 variants (33). Similarly, a recent subset of RBD-specific cross-reactive mAbs also showed in vitro activity (34), although their in vivo breadth and protective efficacy against divergent sarbecoviruses remains unconfirmed. In contrast to DH1047, neither DH1235, DH1073, nor DH1046 fully protected against SARS-CoV infection in aged mice, possibly because these cross-reactive mAbs may have differences in their mechanisms of protection in vivo. Although it is not clear why these mAbs have in vivo protection differences, it is possible that they have differences in their angle of approach to the spike protein, require optimal Fc effector functions (35), or may have stability differences in vivo.

DH1047 had broad protective in vivo efficacy against preemergent SARS-related viruses, epidemic SARS-CoV, SARSCoV-2 B.1.351 variant, and neutralized all tested SARS-CoV-2 variants including the delta variant, underscoring that DH1047 recognizes a pan-sarbecovirus neutralizing epitope. Consistent with this notion, we have described a SARS-CoV2 RBD-ferritin nanoparticle vaccine that elicited neutralizing antibodies against pre-emergent SARS-related viruses and protected against SARS-CoV-2 challenge in non-human primates (9). The serum antibody responses in these SARS-CoV2 RBD-ferritin nanoparticle-vaccinated monkeys could block DH1047 binding responses against SARS-CoV-2 spike proteins, suggesting that SARS-CoV-2 RBD vaccines elicit DH1047-like antibody responses and could potentially protect against the future emergence of SARS-CoV or SARS-CoV2-related viruses. As other broad sarbecovirus vaccine formulations are developed and following a recent study which reported broad neutralization of sarbecoviruses in SARS convalescent patients fully immunized with SARS-CoV-2 mRNA vaccines $(8,36)$, and it will be interesting to examine if these vaccines and individuals generate DH1047-like neutralizing antibodies.

Although we demonstrate the broad protective efficacy of DH1047 in mice, our study has limitations. First, our study does not evaluate the protective breadth of DH1047 against SARS-related viruses in larger animal models, such as nonhuman primates. Second, our study does not evaluate the role of DH1047 Fc region modifications, such as those that more favorably interact with activating Fc receptors, in mediating protection against SARS-related viruses. Future studies should examine if the protective efficacy of DH1047 can be amplified by modulating Fc receptors in vivo.

Moving forward, it will be critical to closely monitor SARS-CoV and SARS-CoV-2-related viruses of zoonotic origin and actively monitor if broad-spectrum antibodies like ADG2, DH1047, and S2X259 retain their inhibitory activity against pre-emergent viruses. We envision a system in which broadspectrum antibodies like DH1047 could be tested for safety in small Phase I clinical trials so that if a future SARS-related virus emerges, DH1047 could immediately be tested in larger efficacy trials at the site of an outbreak to potentially prevent 
the rapid spread of an emergent coronavirus. Moreover, given that DH1047 neutralized all tested SARS-CoV-2 variants including the highly transmissible delta variant, this mAb could also be deployed now to help curb the ongoing COVID-19 pandemic. Like other therapeutic monoclonal antibodies evaluated against COVID-19, our data suggest that early administration will prove critical for protecting against severe disease outcomes (37). We conclude that DH1047 is a broadly protective mAb that has efficacy against pre-emergent, zoonotic SARS-related viruses from different clades, neutralizes highly transmissible SARS-CoV-2 variants of concern, and protects against SARS-CoV-2 B.1.351.

\section{MATERIALS AND METHODS \\ Study design}

The study objective was to discover and characterize broadly neutralizing antibodies that are protective against divergent SARS-related viruses. To this end, mAbs were tested in vitro to examine their binding and neutralizing activity and in vivo to measure their protective efficacy against multiclade sarbecoviruses. mAbs were tested in duplicate in neutralization assays and experiments were repeated independently for rigor and reproducibility. No statistical methods were used to predetermine mouse sample size. All mouse experiments utilized 5 to 10 mice per group. A control mAb-treated group was included in each independent experiment for each different virus. No datapoints were excluded as outliers in any experiment. Naïve BALB/c mice (Envigo \#047) were the same age (around 12 months) and sex (female) for the SARS-CoV MA15, RsSHC014, and SARS-CoV-2 B.1.351 challenge experiments and were randomly assigned to the different $\mathrm{mAb}$ vs. control groups. Male and female eight to 10-week-old hACE2-transgenic mice (B6J.Cg-Tg(FOXJ1ACE2)1Rba/Mmnc) bred at UNC Chapel Hill were equally distributed to the DH1047 and control mAb treatment groups for the WIV-1 challenge experiments. Active animal biosafety level 3 (BSL-3) experiments were not performed blindly. Following the completion of animal BSL-3 experiments and sample collection, all immunological, virological, and histopathological measurements were performed blinded. Immunological and virological samples were assigned new numbers to blind researchers during readouts. Mice were euthanized at day two post infection, which is peak lung viral replication, to rigorously assess mAb-mediated protection against lung viral infection. Mice were euthanized at day four post infection, a time where signs of coronavirus disease are set in these mouse models, to measure weight loss, lung viral replication, lung pathology, pulmonary function, and mortality. All active mouse experiments were carried to completion through day two or day four post infection except when mice reached below 70 percent of their starting weight, a point in which mice were humanely euthanized in accordance with UNC Chapel Hill Institutional Animal Care and Use
Committee (IACUC)-approved protocols. Lung microscopic pathology readouts were performed by a board-certified veterinary pathologist who was blinded to the treatment groups. Neutralization and SPR experiments for DH1047 and control were repeated twice independently with technical replicates in each experiment. DH1047 and CH65 control in vivo protection experiments against SARS-CoV MA15, RsSHC014, WIV1, and SARS-CoV-2 B.1.351 were repeated twice independently.

\section{Biocontainment and biosafety}

Studies were approved by the UNC Institutional Biosafety Committee approved by animal and experimental protocols in the Baric laboratory. All work described here was performed with approved standard operating procedures for SARS-CoV-2 in a BSL-3 facility conforming to requirements recommended in the Microbiological and Biomedical Laboratories, by the U.S. Department of Health and Human Service, the U.S. Public Health Service, and the U.S. Center for Disease Control and Prevention (CDC), and the National Institutes of Health (NIH).

\section{Antibody isolation and measurement of coronavimus spike protein binding by enzyme-linked immuno- sorbent assay (ELISA)}

Monoclonal antibodies were isolated from antigen-specific single B cells from an individual who had recovered from SARS-CoV-1 infection 17 years prior to leukapheresis and from a SARS-CoV-2 convalescent individual 36 days post infection as previously described (15). Monoclonal antibodies were screened by binding ELISAS. Indirect binding ELISAs were conducted in 384 well ELISA plates (Costar \#3700) coated with $2 \mu \mathrm{g} / \mathrm{ml}$ antigen in $0.1 \mathrm{M}$ sodium bicarbonate overnight at $4^{\circ} \mathrm{C}$, washed and blocked with assay diluent (1X phosphate buffered saline (PBS) containing 4\% (w/v) whey protein, 15\% normal goat serum, 0.5\% Tween-20, and 0.05\% sodium azide). mAbs were incubated for $60 \mathrm{~min}$ in three-fold serial dilutions beginning at $100 \mu \mathrm{g} / \mathrm{ml}$ followed by washing with PBS/0.1\% Tween-20. Horseradish peroxidase (HRP)conjugated goat anti-mouse IgG secondary antibody (SouthernBiotech 1030-05) was diluted to 1:10,000 in assay diluent without azide, incubated at for 1 hour at room temperature, washed and detected with $20 \mu$ l SureBlue Reserve (KPL 5300-03) for $15 \mathrm{~min}$. Reactions were stopped via the addition of $20 \mu \mathrm{l}$ HCL stop solution. Plates were read at 450nm. Area under the curve (AUC) measurements were determined from binding of serial dilutions.

\section{Measurement of neutralizing antibodies against live viruses}

Full-length SARS-CoV-2 Seattle, a mouse-adapted SARSCoV-2 2AA Q498Y/P499T, SARS-CoV-2 D614G, SARS-CoV-2 B.1.351, SARS-CoV-2 B.1.1.7, SARS-CoV, WIV-1, and RsSHC014 viruses were designed to express nanoluciferase (nLuc) (8). Virus titers were measured in Vero E6 (C1008) cells, as 
defined by plaque forming units (PFU) per ml, in a 6-well plate format in quadruplicate technical replicates for accuracy. For the 96-well neutralization assay, Vero E6 (C1008) cells were plated at 20,000 cells per well the day prior in clear bottom black walled plates. Cells were inspected to ensure confluency on the day of assay. mAbs were serially diluted three-fold up to nine dilution spots at specified concentrations. Serially diluted mAbs were mixed in equal volume with diluted virus. Antibody-virus and virus only mixtures were then incubated at $37^{\circ} \mathrm{C}$ with $5 \% \mathrm{CO}_{2}$ for one hour. Following incubation, serially diluted mAbs and virus only controls were added in duplicate to the cells at $75 \mathrm{PFU}$ at $37^{\circ} \mathrm{C}$ with $5 \% \mathrm{CO}_{2}$. After 24 hours, cells were lysed, and luciferase activity was measured via Nano-Glo Luciferase Assay System (Promega) according to the manufacturer specifications. Luminescence was measured by a Spectramax M3 plate reader (Molecular Devices). Virus neutralization titers were defined as the sample dilution at which a $50 \%$ reduction in relative light units was observed relative to the average of the virus control wells.

\section{Lentivirus pseudovirus neutralization assay} (PsVNA)

The PsVNA using 293-ACE2-TMPRSS2 cell line was described previously $(38,39)$. Antibody preparations were evaluated by SARS-CoV-2 PsVNA50 using WA-1 strain, B.1.1.7 (with spike protein mutations: H69-V70del, Y144del, N501Y, A570D, D614G, P681H, T716I, S982A, and D1118H), B.1.429 (with spike protein mutations S13I, W152C, L452R, D614G), B.1.526 (with spike protein mutations L5F, T95I, D253G, E484K or S477N, D614G, A701V), P.1 (with spike protein mutations L18F, T20N, P26S, D138Y, R190S, K417T, E484K, N501Y, H655Y, T1027I, D614G, V1176F), B.1.351 (with spike protein mutations L18F, D80A, D215G, L242-244del, K417N, E484K, N501Y, D614G, and A701V), B.1.617.1 (with spike protein mutations G142D, E154K, V382L, L452R, E484Q, P681R, Q1071H, D1153Y) and B.1.617.2 (with spike protein mutations T19R, G142D, E156del, F157del, R158G, L452R, T478K, D614G, P681R, D950N). Controls included cells only, virus without any antibody and positive serum samples. The cut-off value or the limit of detection (LoD) for the neutralization assay was 1:10 dilution.

\section{Surface plasmon resonance}

Kinetic measurements of the DH1047 Fab binding to SARS-CoV and RsSHC014 spike proteins were obtained using a Biacore S200 instrument (Cytiva, formerly GE Healthcare) in HBS-EP+ IX running buffer. The spike proteins were first captured onto a Series S Streptavidin chip to 300 to 400 response units (RU) for the SARS-CoV spike proteins and 850 to $1000 \mathrm{RU}$ for the RsSHC014 spike protein. The DH1047 Fab was diluted from 2.5 to $200 \mathrm{nM}$ and injected over the captured coronavirus spike proteins using the single cycle kinetics injection type at a flow rate of $50 \mu \mathrm{L}$ per minute. There were five
$120 \mathrm{~s}$ injections of the Fab at increasing concentrations followed by a dissociation of $600 \mathrm{~s}$ after the final injection. After dissociation, the spike proteins were regenerated from the streptavidin surface using a $30 \mathrm{~s}$ pulse of Glycine pH1.5. Results were analyzed using the Biacore S200 Evaluation software (Cytiva). A blank streptavidin surface along with blank buffer binding were used for double reference subtraction to account for non-specific protein binding and signal drift. Subsequent curve fitting analyses were performed using a 1:1 Langmuir model with a local Rmax for the DH1047 Fab. The reported binding curves are representative of two data sets.

\section{Biolayer interferometry (BLI)}

Binding assays were performed by biolayer interferometry in an Octet RED384 instrument (Forte Bio). Anti-human IgG (AHQ) biosensor tips were dipped into $200 \mu \mathrm{l}$ of filtered supernatant DH1047 WT or mutant proteins for five minutes at $1000 \mathrm{rpm}$ followed by $1 \mathrm{~min}$ in $1 \mathrm{X}$ PBS. Next, the tips were dipped into $100 \mathrm{nM}$ of purified SARS-CoV-2 2P spike ectodomain and binding response was measured. Non-specific binding was accounted for by using reference subtraction of signal on a senor tip captured with control mock transfection. Analysis was performed on Octet Data Analysis HT software (ForteBio) and visualization and normalization using Prism 9.

\section{Protein expression and purification for EM studies}

The SARS-CoV spike ectodomain construct comprised the residues 1 to 1190 (UniProt P59594-1) with proline substitutions at 968 to 969 , a C-terminal T4 fibritin trimerization motif, a C-terminal HRV3C protease cleavage site, a TwinStrepTag and an 8XHisTag. The construct was cloned into the mammalian expression vector $\mathrm{p} \alpha \mathrm{H}$ (40). The RsSHC014 spike ectodomain construct was prepared similarly, except it also contained the $2 \mathrm{P}$ mutations that placed two consecutive proline at the $\mathrm{HR} 1-\mathrm{CH}$ junction at residue positions 986 and 987. FreeStyle 293F (Thermo Fisher Scientific) cells were used for the spike ectodomain production. Cells were maintained in FreeStyle 293 Expression Medium (Gibco) at $37^{\circ} \mathrm{C}$ and $9 \% \mathrm{CO}_{2}$, with agitation at $120 \mathrm{rpm}$ in a $75 \%$ humidified atmosphere. Transfections were performed as previously described $(41,42)$ using Turbo293 (SpeedBiosystems). Sixteen to 18 hours post transfection, HyClone CDM4HEK293 media (Cytiva) was added. On the sixth day post transfection, spike ectodomain was harvested from the concentrated supernatant. The purification was performed using StrepTactin resin (IBA LifeSciences) and size exclusion chromatography (SEC) on a Superose 6 10/300 GL Increase column (Cytiva) in 2mM Tris, pH 8.0, $200 \mathrm{mM} \mathrm{NaCl}, 0.02 \%$ $\mathrm{NaN}_{3}$. All steps were performed at room temperature and the purified spike proteins were concentrated to 1 to $5 \mathrm{mg} / \mathrm{ml}$, flash frozen in liquid nitrogen and stored at $-80^{\circ} \mathrm{C}$ until further use.

DH1047 IgG was produced in Expi293F (Thermo Fisher 
Scientific) cells maintained in Expi293 Expression Medium (Gibco) at $37^{\circ} \mathrm{C}, 120 \mathrm{rpm}, 8 \% \mathrm{CO}_{2}$ and $75 \%$ humidity. Plasmids were transfected using the ExpiFectamine 293 Transfection Kit and protocol (Gibco) $(41,43)$ and purified by Protein A affinity (EMD Millipore). The IgG was digested to the Fab state using LysC (Thermo Fisher Scientific).

\section{Negative Stain Electron Microscopy (NSEM)}

NSEM was performed as described previously (15). Briefly, Fab-spike protein complexes were prepared by mixing Fab and spike to give a 9:1 molar ratio of $\mathrm{Fab}$ to spike protein. Following an incubation for 1 hour at $37^{\circ} \mathrm{C}$, the complex was cross-linked by diluting to a final spike protein concentration of $0.1 \mathrm{mg} / \mathrm{ml}$ into room-temperature buffer containing 150 $\mathrm{mM} \mathrm{NaCl}, 20 \mathrm{mM}$ HEPES pH 7.4, 5\% glycerol, and $7.5 \mathrm{mM}$ glutaraldehyde and incubating for $5 \mathrm{~min}$. Excess glutaraldehyde was quenched by adding sufficient $1 \mathrm{M}$ Tris $\mathrm{pH}$ 7.4 stock to give a final concentration of $75 \mathrm{mM}$ Tris and incubated for 5 min. Carbon-coated grids (EMS, CF300-cu-UL) were glow-


quenched sample was incubated on the grid for 10 to $15 \mathrm{~s}$, blotted, and then stained with $2 \%$ uranyl formate. After air drying grids were imaged with a Philips EM420 electron microscope operated at $120 \mathrm{kV}$, at 82,000x magnification and images captured with a $2 \mathrm{k} \times 2 \mathrm{kCCD}$ camera at a pixel size of $4.02 \AA$.

The RELION 3.0 program was used for all negative stain image processing. Images were imported, contrast transfer function (CTF)-corrected with CTFFIND, and particles were picked using a spike protein template from previous 2D class averages of spike protein alone. Extracted particle stacks were subjected to two to three rounds of $2 \mathrm{D}$ class averaging and selection to discard junk particles and background picks. Cleaned particle stacks were then subjected to 3D classification using a starting model created from a bare spike protein model, PDB 6vsb, low-pass filtered to $30 \AA$. Classes that showed clearly defined Fabs were selected for final refinements followed by automatic filtering and B-factor sharpening with the default Relion post-processing parameters.

\section{Cryo-EM}

Purified SARS-CoV-1 spike ectodomain was incubated for approximatively 2 hours with a 6 -fold molar equivalent of the DH1047 Fab in a final volume of $10 \mu \mathrm{L}$. The sample concentration was adjusted to about $1.5 \mathrm{mg} / \mathrm{mL}$ of spike protein in $2 \mathrm{mM}$ Tris pH 8.0, $200 \mathrm{mM} \mathrm{NaCl}$, and $0.02 \% \mathrm{NaN}_{3}$. Before freezing, $0.1 \mu \mathrm{L}$ of glycerol was added to the $10 \mu \mathrm{L}$ of sample. A $2.4 \mu \mathrm{L}$ drop of protein was deposited on a Quantifoil-1.2/1.3 grid (Electron Microscopy Sciences) that had been glow discharged for $10 \mathrm{~s}$ using a PELCO easiGlow Glow Discharge Cleaning System. After a $30 \mathrm{~s}$ incubation in greater than $95 \%$ humidity, excess protein was blotted away for $2.5 \mathrm{~s}$ before being plunge frozen into liquid ethane using a Leica EM GP2 plunge freezer (Leica Microsystems). Frozen grids were imaged using a Titan Krios (Thermo Fisher Scientific) equipped with a K3 detector (Gatan). Data processing was performed using cryoSPARC (44). Model building and refinement was done using Phenix $(45,46)$, Coot (47), Pymol (48), Chimera (49), ChimeraX (50) and Isolde (51). Similar to what we had observed for the DH1047 complex with the SARS-CoV2 spike ectodomain (15), there was considerable heterogeneity in the RBD region. Further classification of particles was performed to better resolve the antibody binding interface, resulting in an asymmetric reconstruction of a population refined to a resolution of $3.4 \AA$ that was used for model fitting.

\section{Animals and challenge viruses}

Eleven-month-old female BALB/c mice were purchased from Envigo (\#047) and were used for the SARS-CoV, SARSCoV-2 B.1.351, and RsSHC014-CoV protection experiments. Eight to 10-week-old hACE2-transgenic mice (B6J.Cg$\mathrm{Tg}$ (FOXJ1-ACE2)1Rba/Mmnc) were bred at UNC Chapel Hill and were used for WIV-1-CoV protection experiments. The study was carried out in accordance with the recommendations for care and use of animals by the Office of Laboratory Animal Welfare (OLAW), National Institutes of Health and the Institutional Animal Care and Use Committee (IACUC) of University of North Carolina (UNC permit no. A-3410-01). Animals were housed in groups of five and fed standard chow diets. Virus inoculations were performed under anesthesia and all efforts were made to minimize animal suffering. All mice were anesthetized by injecting xylazine and ketamine intraperitoneally and infected intranasally with $1 \times 10^{4}$ $\mathrm{PFU} / \mathrm{ml}$ of SARS-CoV MA15, $1 \times 10^{4} \mathrm{PFU} / \mathrm{ml}$ of SARS-CoV-2 B.1.351-MA10, $1 \times 10^{4} \mathrm{PFU} / \mathrm{ml}$ RsSHC014 or $1 \times 10^{4} \mathrm{PFU} / \mathrm{ml}$ WIV-1, which have been described previously $(6,52,53)$. Mice were weighted daily and monitored for signs of clinical disease, and selected groups were subjected to daily whole-body plethysmography. For all mouse studies, groups of $n=10$ mice were included per arm of the study except for the hACE2transgenic mice, which included $n=5$ mice per group due to a limited availability of these mice. Viral titers, weight loss, and histology were measured from individual mice per group.

\section{Lung pathology scoring}

Acute lung injury was quantified by two separate lung pathology scoring scales: Matute-Bello and Diffuse Alveolar Damage (DAD) scoring systems. Analyses and scoring were performed by a board certified veterinary pathologist who was blinded to the treatment groups as described previously (54). Lung pathology slides were read and scored at 600X total magnification.

The lung injury scoring system used is from the American Thoracic Society (Matute-Bello) to help quantitate histological features of ALI observed in mouse models to relate this injury to human settings. In a blinded manner, three random fields of lung tissue were chosen and scored for the following: (A) neutrophils in the alveolar space (none $=0,1$ to 5 cells $=$ 
1, greater than 5 cells $=2$ ), (B) neutrophils in the interstitial septa (none $=0,1$ to 5 cells $=1$, greater than 5 cells $=2$ ), $(\mathrm{C})$ hyaline membranes (none $=0$, one membrane $=1$, greater than 1 membrane $=2$ ), (D) Proteinaceous debris in air spaces (none $=0$, one instance $=1$, greater than 1 instance $=2),(E)$ alveolar septal thickening (less than 2x mock thickness $=0,2$ to $4 \mathrm{x}$ mock thickness $=1$, greater than $4 \mathrm{x}$ mock thickness $=$ 2). To obtain a lung injury score per field, A to E scores were put into the following formula score $=[(20 \times \mathrm{A})+(14 \times \mathrm{B})+(7$ $\mathrm{x} C)+(7 \times \mathrm{D})+(2 \times \mathrm{E})] / 100$. This formula contains multipliers that assign varying degrees of importance for each phenotype of the disease state. The scores for the three fields per mouse were averaged to obtain a final score ranging from 0 to and including 1 . The second histology scoring scale to quantify acute lung injury was adopted from a lung pathology scoring system from lung RSV infection in mice (55). This lung histology scoring scale measures diffuse alveolar damage (DAD). Like the implementation of the ATS histology scoring scale, three random fields of lung tissue were scored for the following in a blinded manner: $1=$ absence of cellular sloughing and necrosis, $2=$ uncommon solitary cell sloughing and necrosis ( 1 to 2 foci per field), $3=$ multifocal $(3+$ foci) cellular sloughing and necrosis with uncommon septal wall hyalinization, or $4=$ multifocal (greater than $75 \%$ of field) cellular sloughing and necrosis with common or prominent hyaline membranes. The scores for the three fields per mouse were averaged to get a final DAD score per mouse. The microscope images were generated using an Olympus Bx43 light microscope and CellSense Entry v3.1 software.

\section{Weblogo}

As the interface in the SARS-CoV-2/DH1047 complex was better resolved (15), we used this complex for visualizing epitope details and analyzing extent of conservation of the epitope residues in different sarbecoviruses. The Weblogo tool from UC Berkeley was used to generate the consensus epitopes of the DH1047 HCDR3 and LCDR3 epitopes. https://weblogo.berkeley.edu/logo.cgi . The following 23 sarbecovirus genomes were used for the Weblogo analysis: KT444582, AY278554, AY278741, AY515512, AY525636, KC881005, KC881006, KF367457, MK211376, MN908947, MN996532, MG772933, MG772934, MK211374, DQ412042, DQ648856, MK211378, DQ022305，DQ412043，DQ648857, DQ071615, MK211375, MK211377.

\section{Statistics}

A two-way ANOVA followed by Tukey's multiple comparisons test to adjust for false discovery rates, a one-way ANOVA followed by Dunnett's multiple comparisons to adjust for false discovery rates, or a Mantel-Cox test were used in mouse experiment measurements. See figure legends for details. All statistical analyses were performed using GraphPad Prism 9.

\section{SUPPLEMENTARY MATERIALS}

www.science.org/doi/10.1126/scitranslmed.abj7125

Figs. S1 to S10

Tables S1 to S3

Data file $\mathrm{S} 1$

\section{REFERENCES AND NOTES}

1. J. S. Peiris, S. T. Lai, L. L. M. Poon, Y. Guan, L. Y. C. Yam, W. Lim, J. Nicholls, W. K. S. Yee, W. W. Yan, M. T. Cheung, V. C. C. Cheng, K. H. Chan, D. N. C. Tsang, R. W. H. Yung, T. K. Ng, K. Y. Yuen; SARS study group, Coronavirus as a possible cause of severe acute respiratory syndrome. Lancet 361, 1319-1325 (2003). doi:10.1016/S0140-6736(03)13077-2 Medline

2. J. D. Cherry, P. Krogstad, SARS: The first pandemic of the 21st century. Pediatr. Res. 56, 1-5 (2004). doi:10.1203/01.PDR.0000129184.87042.FC Medline

3. P. Zhou, X.-L. Yang, X.-G. Wang, B. Hu, L. Zhang, W. Zhang, H.-R. Si, Y. Zhu, B. Li, C.L. Huang, H.-D. Chen, J. Chen, Y. Luo, H. Guo, R.-D. Jiang, M.-Q. Liu, Y. Chen, X.-R. Shen, X. Wang, X.-S. Zheng, K. Zhao, Q.-J. Chen, F. Deng, L.-L. Liu, B. Yan, F.-X. Zhan, Y.-Y. Wang, G.-F. Xiao, Z.-L. Shi, A pneumonia outbreak associated with a new coronavirus of probable bat origin. Nature 579, 270-273 (2020). doi:10.1038/s41586-020-2012-7 Medline

4. W. Li, Z. Shi, M. Yu, W. Ren, C. Smith, J. H. Epstein, H. Wang, G. Crameri, Z. Hu, H. Zhang, J. Zhang, J. McEachern, H. Field, P. Daszak, B. T. Eaton, S. Zhang, L.-F. Wang, Bats are natural reservoirs of SARS-like coronaviruses. Science 310, 676679 (2005). doi:10.1126/science.1118391 Medline

5. B. Hu, L.-P. Zeng, X.-L. Yang, X.-Y. Ge, W. Zhang, B. Li, J.-Z. Xie, X.-R. Shen, Y.-Z. Zhang, N. Wang, D.-S. Luo, X.-S. Zheng, M.-N. Wang, P. Daszak, L.-F. Wang, J. Cui, Z.-L. Shi, Discovery of a rich gene pool of bat SARS-related coronaviruses provides new insights into the origin of SARS coronavirus. PLOS Pathog. 13, e1006698 (2017). doi:10.1371/journal.ppat.1006698 Medline

6. V. D. Menachery, B. L. Yount Jr., K. Debbink, S. Agnihothram, L. E. Gralinski, J. A. Plante, R. L. Graham, T. Scobey, X.-Y. Ge, E. F. Donaldson, S. H. Randell, A. Lanzavecchia, W. A. Marasco, Z.-L. Shi, R. S. Baric, A SARS-like cluster of circulating bat coronaviruses shows potential for human emergence. Nat. Med. 21, 1508-1513 (2015). doi:10.1038/nm.3985 Medline

7. V. D. Menachery, B. L. Yount Jr., A. C. Sims, K. Debbink, S. S. Agnihothram, L. E. Gralinski, R. L. Graham, T. Scobey, J. A. Plante, S. R. Royal, J. Swanstrom, T. P. Sheahan, R. J. Pickles, D. Corti, S. H. Randell, A. Lanzavecchia, W. A. Marasco, R. S. Baric, SARS-like WIV1-CoV poised for human emergence. Proc. Natl. Acad. Sci. U.S.A. 113, 3048-3053 (2016). doi:10.1073/pnas.1517719113 Medline

8. D. R. Martinez, A. Schäfer, S. R. Leist, G. De la Cruz, A. West, E. N. AtochinaVasserman, L. C. Lindesmith, N. Pardi, R. Parks, M. Barr, D. Li, B. Yount, K. O. Saunders, D. Weissman, B. F. Haynes, S. A. Montgomery, R. S. Baric, Chimeric spike mRNA vaccines protect against Sarbecovirus challenge in mice. Science 373, 991-998 (2021). doi:10.1126/science. abi4506 Medline

9. K. O. Saunders, E. Lee, R. Parks, D. R. Martinez, D. Li, H. Chen, R. J. Edwards, S. Gobeil, M. Barr, K. Mansouri, S. M. Alam, L. L. Sutherland, F. Cai, A. M. Sanzone, M. Berry, K. Manne, K. W. Bock, M. Minai, B. M. Nagata, A. B. Kapingidza, M. Azoitei, L. V. Tse, T. D. Scobey, R. L. Spreng, R. W. Rountree, C. T. DeMarco, T. N. Denny, C. W. Woods, E. W. Petzold, J. Tang, T. H. Oguin 3rd, G. D. Sempowski, M. Gagne, D. C. Douek, M. A. Tomai, C. B. Fox, R. Seder, K. Wiehe, D. Weissman, N. Pardi, H. Golding, S. Khurana, P. Acharya, H. Andersen, M. G. Lewis, I. N. Moore, D. C. Montefiori, R. S. Baric, B. F. Haynes, Neutralizing antibody vaccine for pandemic and pre-emergent coronaviruses. Nature 594, 553-559 (2021). doi:10.1038/s41586-021-03594-0 Medline

10. A. C. Walls, M. C. Miranda, A. Schäfer, M. N. Pham, A. Greaney, P. S. Arunachalam, M.-J. Navarro, M. A. Tortorici, K. Rogers, M. A. O'Connor, L. Shirreff, D. E. Ferrell, J. Bowen, N. Brunette, E. Kepl, S. K. Zepeda, T. Starr, C.-L. Hsieh, B. Fiala, S. Wrenn, D. Pettie, C. Sydeman, K. R. Sprouse, M. Johnson, A. Blackstone, R. Ravichandran, C. Ogohara, L. Carter, S. W. Tilles, R. Rappuoli, S. R. Leist, D. R. Martinez, M. Clark, R. Tisch, D. T. O'Hagan, R. Van Der Most, W. C. Van Voorhis, D. Corti, J. S. McLellan, H. Kleanthous, T. P. Sheahan, K. D. Smith, D. H. Fuller, F. Villinger, J. Bloom, B. Pulendran, R. S. Baric, N. P. King, D. Veesler, Elicitation of broadly protective sarbecovirus immunity by receptor-binding domain nanoparticle vaccines. Cell 184, 5432-5447.e16 (2021). doi:10.1016/i.cell.2021.09.015 Medline

11. R. E. Chen, X. Zhang, J. B. Case, E. S. Winkler, Y. Liu, L. A. VanBlargan, J. Liu, J. M. 
Errico, X. Xie, N. Suryadevara, P. Gilchuk, S. J. Zost, S. Tahan, L. Droit, J. S. Turner, W. Kim, A. J. Schmitz, M. Thapa, D. Wang, A. C. M. Boon, R. M. Presti, J. A. O'Halloran, A. H. J. Kim, P. Deepak, D. Pinto, D. H. Fremont, J. E. Crowe Jr., D. Corti, H. W. Virgin, A. H. Ellebedy, P.-Y. Shi, M. S. Diamond, Resistance of SARS-CoV-2 variants to neutralization by monoclonal and serum-derived polyclonal antibodies. Nat. Med. 27, 717-726 (2021). doi:10.1038/s41591-021-01294-w Medline

12. D. Li, G. D. Sempowski, K. O. Saunders, P. Acharya, B. F. Haynes, SARS-CoV-2 Neutralizing Antibodies for COVID-19 Prevention and Treatment. Annu. Rev. Med. 73, annurev-med-042420-113838 (2021). doi:10.1146/annurev-med-042420$\underline{113838}$ Medline

13. L. Wang, T. Zhou, Y. Zhang, E. S. Yang, C. A. Schramm, W. Shi, A. Pegu, O. K. Oloniniyi, A. R. Henry, S. Darko, S. R. Narpala, C. Hatcher, D. R. Martinez, Y. Tsybovsky, E. Phung, O. M. Abiona, A. Antia, E. M. Cale, L. A. Chang, M. Choe, K. S. Corbett, R. L. Davis, A. T. DiPiazza, I. J. Gordon, S. H. Hait, T. Hermanus, P. Kgagudi, F. Laboune, K. Leung, T. Liu, R. D. Mason, A. F. Nazzari, L. Novik, S. O'Connell, S. O'Dell, A. S. Olia, S. D. Schmidt, T. Stephens, C. D. Stringham, C. A. Talana, I.-T. Teng, D. A. Wagner, A. T. Widge, B. Zhang, M. Roederer, J. E. Ledgerwood, T. J. Ruckwardt, M. R. Gaudinski, P. L. Moore, N. A. Doria-Rose, R. S. Baric, B. S. Graham, A. B. McDermott, D. C. Douek, P. D. Kwong, J. R. Mascola, N. J. Sullivan, J. Misasi, Ultrapotent antibodies against diverse and highly transmissible SARS-CoV-2 variants. Science 373, eabh1766 (2021). doi:10.1126/science.abh1766 Medline

14. C. G. Rappazzo, L. V. Tse, C. I. Kaku, D. Wrapp, M. Sakharkar, D. Huang, L. M. Deveau, T. J. Yockachonis, A. S. Herbert, M. B. Battles, C. M. O'Brien, M. E. Brown, J. C. Geoghegan, J. Belk, L. Peng, L. Yang, Y. Hou, T. D. Scobey, D. R. Burton, D. Nemazee, J. M. Dye, J. E. Voss, B. M. Gunn, J. S. McLellan, R. S. Baric, L. E. Gralinski, L. M. Walker, Broad and potent activity against SARS-like viruses by an engineered human monoclonal antibody. Science 371, 823-829 (2021). doi:10.1126/science. abf4830 Medline

15. D. Li, R. J. Edwards, K. Manne, D. R. Martinez, A. Schäfer, S. M. Alam, K. Wiehe, X. Lu, R. Parks, L. L. Sutherland, T. H. Oguin 3rd, C. McDanal, L. G. Perez, K. Mansouri, S. M. C. Gobeil, K. Janowska, V. Stalls, M. Kopp, F. Cai, E. Lee, A. Foulger, G. E. Hernandez, A. Sanzone, K. Tilahun, C. Jiang, L. V. Tse, K. W. Bock, M. Minai, B. M. Nagata, K. Cronin, V. Gee-Lai, M. Deyton, M. Barr, T. Von Holle, A. N. Macintyre, E. Stover, J. Feldman, B. M. Hauser, T. M. Caradonna, T. D. Scobey, W. Rountree, Y. Wang, M. A. Moody, D. W. Cain, C. T. DeMarco, T. N. Denny, C. W. Woods, E. W. Petzold, A. G. Schmidt, I.-T. Teng, T. Zhou, P. D. Kwong, J. R. Mascola, B. S. Graham, I. N. Moore, R. Seder, H. Andersen, M. G. Lewis, D. C. Montefiori, G. D. Sempowski, R. S. Baric, P. Acharya, B. F. Haynes, K. O. Saunders, In vitro and in vivo functions of SARS-CoV-2 infection-enhancing and neutralizing antibodies. Cell 184, 4203-4219.e32 (2021). doi:10.1016/i.cell.2021.06.021 Medline

16. J. R. Whittle, R. Zhang, S. Khurana, L. R. King, J. Manischewitz, H. Golding, P. R. Dormitzer, B. F. Haynes, E. B. Walter, M. A. Moody, T. B. Kepler, H.-X. Liao, S. C. Harrison, Broadly neutralizing human antibody that recognizes the receptorbinding pocket of influenza virus hemagglutinin. Proc. Natl. Acad. Sci. U.S.A. 108 14216-14221 (2011). doi:10.1073/pnas.1111497108 Medline

17. S. R. Leist, A. Schäfer, D. R. Martinez, Cell and animal models of SARS-CoV-2 pathogenesis and immunity. Dis. Model. Mech. 13, dmm046581 (2020). doi:10.1242/dmm.046581 Medline

18. D. Planas, T. Bruel, L. Grzelak, F. Guivel-Benhassine, I. Staropoli, F. Porrot, C. Planchais, J. Buchrieser, M. M. Rajah, E. Bishop, M. Albert, F. Donati, M. Prot, S. Behillil, V. Enouf, M. Maquart, M. Smati-Lafarge, E. Varon, F. Schortgen, L. Yahyaoui, M. Gonzalez, J. De Sèze, H. Péré, D. Veyer, A. Sève, E. Simon-Lorière, S. Fafi-Kremer, K. Stefic, H. Mouquet, L. Hocqueloux, S. van der Werf, T. Prazuck, O. Schwartz, Sensitivity of infectious SARS-CoV-2 B.1.1.7 and B.1.351 variants to neutralizing antibodies. Nat. Med. 27, 917-924 (2021). doi:10.1038/s41591-02101318-5 Medline

19. C. O. Barnes, C. A. Jette, M. E. Abernathy, K. A. Dam, S. R. Esswein, H. B. Gristick, A. G. Malyutin, N. G. Sharaf, K. E. Huey-Tubman, Y. E. Lee, D. F. Robbiani, M. C. Nussenzweig, A. P. West Jr., P. J. Bjorkman, SARS-CoV-2 neutralizing antibody structures inform therapeutic strategies. Nature 588, 682-687 (2020). doi:10.1038/s41586-020-2852-1 Medline

20. Z. Lv, Y.-Q. Deng, Q. Ye, L. Cao, C.-Y. Sun, C. Fan, W. Huang, S. Sun, Y. Sun, L. Zhu, Q. Chen, N. Wang, J. Nie, Z. Cui, D. Zhu, N. Shaw, X.-F. Li, Q. Li, L. Xie, Y. Wang, Z.
Rao, C.-F. Qin, X. Wang, Structural basis for neutralization of SARS-CoV-2 and SARS-CoV by a potent therapeutic antibody. Science 369, 1505-1509 (2020). doi:10.1126/science. abc5881 Medline

21. L. Piccoli, Y.-J. Park, M. A. Tortorici, N. Czudnochowski, A. C. Walls, M. Beltramello, C. Silacci-Fregni, D. Pinto, L. E. Rosen, J. E. Bowen, O. J. Acton, S. Jaconi, B. Guarino, A. Minola, F. Zatta, N. Sprugasci, J. Bassi, A. Peter, A. De Marco, J. C. Nix, F. Mele, S. Jovic, B. F. Rodriguez, S. V. Gupta, F. Jin, G. Piumatti, G. Lo Presti, A. F. Pellanda, M. Biggiogero, M. Tarkowski, M. S. Pizzuto, E. Cameroni, C. HavenarDaughton, M. Smithey, D. Hong, V. Lepori, E. Albanese, A. Ceschi, E. Bernasconi, L. Elzi, P. Ferrari, C. Garzoni, A. Riva, G. Snell, F. Sallusto, K. Fink, H. W. Virgin, A. Lanzavecchia, D. Corti, D. Veesler, Mapping Neutralizing and Immunodominant Sites on the SARS-CoV-2 Spike Receptor-Binding Domain by Structure-Guided High-Resolution Serology. Cell 183, 1024-1042.e21 (2020). doi:10.1016/i.cell.2020.09.037 Medline

22. D. Zhou, H. M. E. Duyvesteyn, C.-P. Chen, C.-G. Huang, T.-H. Chen, S.-R. Shih, Y.C. Lin, C.-Y. Cheng, S.-H. Cheng, Y.-C. Huang, T.-Y. Lin, C. Ma, J. Huo, L. Carrique, T. Malinauskas, R. R. Ruza, P. N. M. Shah, T. K. Tan, P. Rijal, R. F. Donat, K. Godwin, K. R. Buttigieg, J. A. Tree, J. Radecke, N. G. Paterson, P. Supasa, J. Mongkolsapaya, G. R. Screaton, M. W. Carroll, J. Gilbert-Jaramillo, M. L. Knight, W. James, R. J. Owens, J. H. Naismith, A. R. Townsend, E. E. Fry, Y. Zhao, J. Ren, D. I. Stuart, K. A. Huang, Structural basis for the neutralization of SARS-CoV-2 by an antibody from a convalescent patient. Nat. Struct. Mol. Biol. 27, 950-958 (2020). doi:10.1038/s41594-020-0480-y Medline

23. H. Liu, N. C. Wu, M. Yuan, S. Bangaru, J. L. Torres, T. G. Caniels, J. van Schooten, X. Zhu, C. D. Lee, P. J. M. Brouwer, M. J. van Gils, R. W. Sanders, A. B. Ward, I. A. Wilson, Cross-Neutralization of a SARS-CoV-2 Antibody to a Functionally Conserved Site Is Mediated by Avidity. Immunity 53, 1272-1280.e5 (2020). doi:10.1016/i.immuni.2020.10.023 Medline

24. K. M. Hastie, H. Li, D. Bedinger, S. L. Schendel, S. M. Dennison, K. Li, V. Rayaprolu, X. Yu, C. Mann, M. Zandonatti, R. Diaz Avalos, D. Zyla, T. Buck, S. Hui, K. Shaffer, C. Hariharan, J. Yin, E. Olmedillas, A. Enriquez, D. Parekh, M. Abraha, E. Feeney, G. Q. Horn, Y. Aldon, H. Ali, S. Aracic, R. R. Cobb, R. S. Federman, J. M. Fernandez, J. Glanville, R. Green, G. Grigoryan, A. G. Lujan Hernandez, D. D. Ho, K. A. Huang, J. Ingraham, W. Jiang, P. Kellam, C. Kim, M. Kim, H. M. Kim, C. Kong, S. J. Krebs, F. Lan, G. Lang, S. Lee, C. L. Leung, J. Liu, Y. Lu, A. MacCamy, A. T. McGuire, A. L. Palser, T. H. Rabbitts, Z. Rikhtegaran Tehrani, M. M. Sajadi, R. W. Sanders, A. K. Sato, L. Schweizer, J. Seo, B. Shen, J. L. Snitselaar, L. Stamatatos, Y. Tan, M. T. Tomic, M. J. van Gils, S. Youssef, J. Yu, T. Z. Yuan, Q. Zhang, B. Peters, G. D. Tomaras, T. Germann, E. O. Saphire; CoVIC-DB team1, Defining variant-resistant epitopes targeted by SARS-CoV-2 antibodies: A global consortium study. Science 374, 472-478 (2021). Medline

25. N. G. Davies, S. Abbott, R. C. Barnard, C. I. Jarvis, A. J. Kucharski, J. D. Munday, C. A. B. Pearson, T. W. Russell, D. C. Tully, A. D. Washburne, T. Wenseleers, A. Gimma, W. Waites, K. L. M. Wong, K. van Zandvoort, J. D. Silverman, K. Diaz-Ordaz, R. Keogh, R. M. Eggo, S. Funk, M. Jit, K. E. Atkins, W. J. Edmunds; CMMID COVID19 Working Group; COVID-19 Genomics UK (COG-UK) Consortium, Estimated transmissibility and impact of SARS-CoV-2 lineage B.1.1.7 in England. Science 372, eabg3055 (2021). doi:10.1126/science.abg3055 Medline

26. N. G. Davies, C. I. Jarvis, W. J. Edmunds, N. P. Jewell, K. Diaz-Ordaz, R. H. Keogh; CMMID COVID-19 Working Group, Increased mortality in community-tested cases of SARS-CoV-2 lineage B.1.1.7. Nature 593, 270-274 (2021). doi:10.1038/s41586-021-03426-1 Medline

27. C. Liu, H. M. Ginn, W. Dejnirattisai, P. Supasa, B. Wang, A. Tuekprakhon, R. Nutalai, D. Zhou, A. J. Mentzer, Y. Zhao, H. M. E. Duyvesteyn, C. López-Camacho, J. SlonCampos, T. S. Walter, D. Skelly, S. A. Johnson, T. G. Ritter, C. Mason, S. A. Costa Clemens, F. Gomes Naveca, V. Nascimento, F. Nascimento, C. Fernandes da Costa, P. C. Resende, A. Pauvolid-Correa, M. M. Siqueira, C. Dold, N. Temperton, T. Dong, A. J. Pollard, J. C. Knight, D. Crook, T. Lambe, E. Clutterbuck, S. Bibi, A. Flaxman, M. Bittaye, S. Belij-Rammerstorfer, S. C. Gilbert, T. Malik, M. W. Carroll, P. Klenerman, E. Barnes, S. J. Dunachie, V. Baillie, N. Serafin, Z. Ditse, K. Da Silva, N. G. Paterson, M. A. Williams, D. R. Hall, S. Madhi, M. C. Nunes, P. Goulder, E. E. Fry, J. Mongkolsapaya, J. Ren, D. I. Stuart, G. R. Screaton, Reduced neutralization of SARS-CoV-2 B.1.617 by vaccine and convalescent serum. Cell 184, 42204236.e13 (2021). doi:10.1016/i.cell.2021.06.020 Medline

28. P. Wang, M. S. Nair, L. Liu, S. Iketani, Y. Luo, Y. Guo, M. Wang, J. Yu, B. Zhang, P. 
D. Kwong, B. S. Graham, J. R. Mascola, J. Y. Chang, M. T. Yin, M. Sobieszczyk, C. A. Kyratsous, L. Shapiro, Z. Sheng, Y. Huang, D. D. Ho, Antibody resistance of SARS-CoV-2 variants B.1.351 and B.1.1.7. Nature 593, 130-135 (2021). Medline

29. J. Sadoff, G. Gray, A. Vandebosch, V. Cárdenas, G. Shukarev, B. Grinsztejn, P. A. Goepfert, C. Truyers, H. Fennema, B. Spiessens, K. Offergeld, G. Scheper, K. L. Taylor, M. L. Robb, J. Treanor, D. H. Barouch, J. Stoddard, M. F. Ryser, M. A. Marovich, K. M. Neuzil, L. Corey, N. Cauwenberghs, T. Tanner, K. Hardt, J. RuizGuiñazú, M. Le Gars, H. Schuitemaker, J. Van Hoof, F. Struyf, M. Douoguih; ENSEMBLE Study Group, Safety and Efficacy of Single-Dose Ad26.COV2.S Vaccine against Covid-19. N. Engl. J. Med. 384, 2187-2201 (2021). doi:10.1056/NEJMoa2101544 Medline

30. S. A. Madhi, V. Baillie, C. L. Cutland, M. Voysey, A. L. Koen, L. Fairlie, S. D. Padayachee, K. Dheda, S. L. Barnabas, Q. E. Bhorat, C. Briner, G. Kwatra, K. Ahmed, P. Aley, S. Bhikha, J. N. Bhiman, A. E. Bhorat, J. du Plessis, A. Esmail, M. Groenewald, E. Horne, S.-H. Hwa, A. Jose, T. Lambe, M. Laubscher, M. Malahleha, M. Masenya, M. Masilela, S. McKenzie, K. Molapo, A. Moultrie, S. Oelofse, F. Patel, S. Pillay, S. Rhead, H. Rodel, L. Rossouw, C. Taoushanis, H. Tegally, A. Thombrayil, S. van Eck, C. K. Wibmer, N. M. Durham, E. J. Kelly, T. L. Villafana, S. Gilbert, A. J. Pollard, T. de Oliveira, P. L. Moore, A. Sigal, A. Izu; NGS-SA Group; Wits-VIDA COVID Group, Efficacy of the ChAdOx1 nCoV-19 Covid-19 Vaccine against the B.1.351 Variant. N. Engl. J. Med. 384, 1885-1898 (2021). doi:10.1056/NEJMoa2102214 Medline

31. Z. Wang, F. Schmidt, Y. Weisblum, F. Muecksch, C. O. Barnes, S. Finkin, D. Schaefer-Babajew, M. Cipolla, C. Gaebler, J. A. Lieberman, T. Y. Oliveira, Z. Yang, M. E. Abernathy, K. E. Huey-Tubman, A. Hurley, M. Turroja, K. A. West, K. Gordon, K. G. Millard, V. Ramos, J. Da Silva, J. Xu, R. A. Colbert, R. Patel, J. Dizon, C. UnsonO'Brien, I. Shimeliovich, A. Gazumyan, M. Caskey, P. J. Bjorkman, R. Casellas, T. Hatziioannou, P. D. Bieniasz, M. C. Nussenzweig, mRNA vaccine-elicited antibodies to SARS-CoV-2 and circulating variants. Nature 592, 616-622 (2021). Medline

32. M. A. Tortorici, N. Czudnochowski, T. N. Starr, R. Marzi, A. C. Walls, F. Zatta, J. E. Bowen, S. Jaconi, J. Di lulio, Z. Wang, A. De Marco, S. K. Zepeda, D. Pinto, Z. Liu, M. Beltramello, I. Bartha, M. P. Housley, F. A. Lempp, L. E. Rosen, E. Dellota Jr., H. Kaiser, M. Montiel-Ruiz, J. Zhou, A. Addetia, B. Guarino, K. Culap, N. Sprugasci, C. Saliba, E. Vetti, I. Giacchetto-Sasselli, C. S. Fregni, R. Abdelnabi, S. C. Foo, C. Havenar-Daughton, M. A. Schmid, F. Benigni, E. Cameroni, J. Neyts, A. Telenti, H. W. Virgin, S. P. J. Whelan, G. Snell, J. D. Bloom, D. Corti, D. Veesler, M. S. Pizzuto, Broad sarbecovirus neutralization by a human monoclonal antibody. Nature 597 , 103-108 (2021). doi:10.1038/s41586-021-03817-4 Medline

33. L. A. VanBlargan, L. J. Adams, Z. Liu, R. E. Chen, P. Gilchuk, S. Raju, B. K. Smith, H. Zhao, J. B. Case, E. S. Winkler, B. M. Whitener, L. Droit, I. D. Aziati, T. L. Bricker, A. Joshi, P.-Y. Shi, A. Creanga, A. Pegu, S. A. Handley, D. Wang, A. C. M. Boon, J. E. Crowe Jr., S. P. J. Whelan, D. H. Fremont, M. S. Diamond, A potently neutralizing SARS-CoV-2 antibody inhibits variants of concern by utilizing unique binding residues in a highly conserved epitope. Immunity 54, 2399-2416.e6 (2021). doi:10.1016/i.immuni.2021.08.016 Medline

34. C. A. Jette, A. A. Cohen, P. N. P. Gnanapragasam, F. Muecksch, Y. E. Lee, K. E. Huey-Tubman, F. Schmidt, T. Hatziioannou, P. D. Bieniasz, M. C. Nussenzweig, A. P. West Jr., J. R. Keeffe, P. J. Bjorkman, C. O. Barnes, Broad cross-reactivity across sarbecoviruses exhibited by a subset of COVID-19 donor-derived neutralizing antibodies. Cell Rep. 36, 109760 (2021). doi:10.1016/i.celrep.2021.109760 Medline

35. R. Yamin, A. T. Jones, H.-H. Hoffmann, A. Schäfer, K. S. Kao, R. L. Francis, T. P. Sheahan, R. S. Baric, C. M. Rice, J. V. Ravetch, S. Bournazos, Fc-engineered antibody therapeutics with improved anti-SARS-CoV-2 efficacy. Nature (2021). doi:10.1038/s41586-021-04017-w Medline

36. C. W. Tan, W.-N. Chia, B. E. Young, F. Zhu, B.-L. Lim, W.-R. Sia, T.-L. Thein, M. I.-C. Chen, Y.-S. Leo, D. C. Lye, L.-F. Wang, Pan-Sarbecovirus Neutralizing Antibodies in BNT162b2-Immunized SARS-CoV-1 Survivors. N. Engl. J. Med. 385, 1401-1406 (2021). doi:10.1056/NEJMoa2108453 Medline

37. D. R. Martinez, A. Schäfer, S. R. Leist, D. Li, K. Gully, B. Yount, J. Y. Feng, E. Bunyan, D. P. Porter, T. Cihlar, S. A. Montgomery, B. F. Haynes, R. S. Baric, M. C. Nussenzweig, T. P. Sheahan, Prevention and therapy of SARS-CoV-2 and the B.1.351 variant in mice. Cell Rep. 36, 109450 (2021). Medline

38. S. Ravichandran, E. M. Coyle, L. Klenow, J. Tang, G. Grubbs, S. Liu, T. Wang, H.
Golding. S. Khurana, Antibody signature induced by SARS-CoV-2 spike protein immunogens in rabbits. Sci. Transl. Med. 12, eabc3539 (2020). doi:10.1126/scitranslmed.abc3539 Medline

39. J. Tang, S. Ravichandran, Y. Lee, G. Grubbs, E. M. Coyle, L. Klenow, H. Genser, H. Golding, S. Khurana, Antibody affinity maturation and plasma IgA associate with clinical outcome in hospitalized COVID-19 patients. Nat. Commun. 12, 1221(2021). doi:10.1038/s41467-021-21463-2 Medline

40. D. Wrapp, N. Wang, K. S. Corbett, J. A. Goldsmith, C.-L. Hsieh, O. Abiona, B. S. Graham, J. S. McLellan, Cryo-EM structure of the 2019-nCoV spike in the prefusion conformation. Science 367, 1260-1263 (2020). doi:10.1126/science.abb2507 Medline

41. R. Henderson, R. J. Edwards, K. Mansouri, K. Janowska, V. Stalls, S. M. C. Gobeil, M. Kopp, D. Li, R. Parks, A. L. Hsu, M. J. Borgnia, B. F. Haynes, P. Acharya, Controlling the SARS-CoV-2 spike glycoprotein conformation. Nat. Struct. Mol. Biol. 27, 925-933 (2020). doi:10.1038/s41594-020-0479-4 Medline

42. R. J. Edwards, K. Mansouri, V. Stalls, K. Manne, B. Watts, R. Parks, K. Janowska, S. M. C. Gobeil, M. Kopp, D. Li, X. Lu, Z. Mu, M. Deyton, T. H. Oguin 3rd, J. Sprenz, W. Williams, K. O. Saunders, D. Montefiori, G. D. Sempowski, R. Henderson, S. Munir Alam, B. F. Haynes, P. Acharya, Cold sensitivity of the SARS-CoV-2 spike ectodomain. Nat. Struct. Mol. Biol. 28, 128-131 (2021). doi:10.1038/s41594-02000547-5 Medline

43. W. B. Williams, R. R. Meyerhoff, R. J. Edwards, H. Li, K. Manne, N. I. Nicely, R. Henderson, Y. Zhou, K. Janowska, K. Mansouri, S. Gobeil, T. Evangelous, B. Hora, M. Berry, A. Y. Abuahmad, J. Sprenz, M. Deyton, V. Stalls, M. Kopp, A. L. Hsu, M. J. Borgnia, G. B. E. Stewart-Jones, M. S. Lee, N. Bronkema, M. A. Moody, K. Wiehe, T. Bradley, S. M. Alam, R. J. Parks, A. Foulger, T. Oguin, G. D. Sempowski, M. Bonsignori, C. C. LaBranche, D. C. Montefiori, M. Seaman, S. Santra, J. Perfect, J. R. Francica, G. M. Lynn, B. Aussedat, W. E. Walkowicz, R. Laga, G. Kelsoe, K. O. Saunders, D. Fera, P. D. Kwong, R. A. Seder, A. Bartesaghi, G. M. Shaw, P. Acharya, B. F. Haynes, Fab-dimerized glycan-reactive antibodies are a structural category of natural antibodies. Cell 184, 2955-2972.e25 (2021). doi:10.1016/i.cell.2021.04.042 Medline

44. A. Punjani, J. L. Rubinstein, D. J. Fleet, M. A. Brubaker, cryoSPARC: Algorithms for rapid unsupervised cryo-EM structure determination. Nat. Methods 14, 290-296 (2017). doi:10.1038/nmeth.4169 Medline

45. D. Liebschner, P. V. Afonine, M. L. Baker, G. Bunkóczi, V. B. Chen, T. I. Croll, B. Hintze, L.-W. Hung, S. Jain, A. J. McCoy, N. W. Moriarty, R. D. Oeffner, B. K. Poon, M. G. Prisant, R. J. Read, J. S. Richardson, D. C. Richardson, M. D. Sammito, O. V. Sobolev, D. H. Stockwell, T. C. Terwilliger, A. G. Urzhumtsev, L. L. Videau, C. J. Williams, P. D. Adams, Macromolecular structure determination using X-rays, neutrons and electrons: Recent developments in Phenix. Acta Crystallogr. D Struct. Biol. 75, 861-877 (2019). doi:10.1107/S2059798319011471 Medline

46. P. V. Afonine, B. K. Poon, R. J. Read, O. V. Sobolev, T. C. Terwilliger, A. Urzhumtsev, P. D. Adams, Real-space refinement in PHENIX for cryo-EM and crystallography. Acta Crystallogr. D Struct. Biol. 74, 531-544 (2018). doi:10.1107/S2059798318006551 Medline

47. P. Emsley, B. Lohkamp, W. G. Scott, K. Cowtan, Features and development of Coot. Acta Crystallogr. D Biol. Crystallogr. 66, 486-501 (2010). doi:10.1107/S0907444910007493 Medline

48. L. Schrodinger, The PyMOL Molecular Graphics System. (2015).

49. E. F. Pettersen, T. D. Goddard, C. C. Huang, G. S. Couch, D. M. Greenblatt, E. C. Meng, T. E. Ferrin, UCSF Chimera-A visualization system for exploratory research and analysis. J. Comput. Chem. 25, 1605-1612 (2004). doi:10.1002/jcc.20084 Medline

50. T. D. Goddard, C. C. Huang, E. C. Meng, E. F. Pettersen, G. S. Couch, J. H. Morris, T. E. Ferrin, UCSF ChimeraX: Meeting modern challenges in visualization and analysis. Protein Sci. 27, 14-25 (2018). doi:10.1002/pro.3235 Medline

51. T. I. Croll, ISOLDE: A physically realistic environment for model building into lowresolution electron-density maps. Acta Crystallogr. D Struct. Biol. 74, 519-530 (2018). doi:10.1107/S2059798318002425 Medline

52. S. R. Leist, K. H. Dinnon 3rd, A. Schäfer, L. V. Tse, K. Okuda, Y. J. Hou, A. West, C. E. Edwards, W. Sanders, E. J. Fritch, K. L. Gully, T. Scobey, A. J. Brown, T. P. Sheahan, N. J. Moorman, R. C. Boucher, L. E. Gralinski, S. A. Montgomery, R. S. Baric, A Mouse-Adapted SARS-CoV-2 Induces Acute Lung Injury and Mortality in Standard Laboratory Mice. Cell 183, 1070-1085.e12 (2020). 
doi:10.1016/i.cell.2020.09.050 Medline

53. A. Roberts, D. Deming, C. D. Paddock, A. Cheng, B. Yount, L. Vogel, B. D. Herman, T. Sheahan, M. Heise, G. L. Genrich, S. R. Zaki, R. Baric, K. Subbarao, A mouseadapted SARS-coronavirus causes disease and mortality in BALB/c mice. PLOS Pathog. 3, e5 (2007). doi:10.1371/journal.ppat.0030005 Medline

54. T. P. Sheahan, A. C. Sims, S. R. Leist, A. Schäfer, J. Won, A. J. Brown, S. A. Montgomery, A. Hogg, D. Babusis, M. O. Clarke, J. E. Spahn, L. Bauer, S. Sellers, D. Porter, J. Y. Feng, T. Cihlar, R. Jordan, M. R. Denison, R. S. Baric, Comparative therapeutic efficacy of remdesivir and combination lopinavir, ritonavir, and interferon beta against MERS-CoV. Nat. Commun. 11, 222 (2020). doi:10.1038/s41467-019-13940-6 Medline

55. M. E. Schmidt, C. J. Knudson, S. M. Hartwig, L. L. Pewe, D. K. Meyerholz, R. A. Langlois, J. T. Harty, S. M. Varga, Memory CD8 T cells mediate severe immunopathology following respiratory syncytial virus infection. PLOS Pathog. 14, e1006810 (2018). doi:10.1371/journal.ppat.1006810 Medline

Acknowledgments: We thank Nilakshee Bhattacharya and Mark Walters for microscope alignments and assistance with cryo-EM data collection. This study utilized the computational resources offered by Duke Research Computing (http://rc.duke.edu; NIH 1S100D018164-01) at Duke University. We thank C. Kneifel, M. Newton, V. Orlikowski, T. Milledge, and D. Lane from the Duke Office of Information Technology and Research Computing for assisting with setting up and maintaining the computing environment. We thank A. Foulger, N. Jamieson, J. Kittrell, E. Lee, and A. Sanzone for DNA and antibody production. Funding: D.R.M. is currently supported by a Burroughs Wellcome Fund Postdoctoral Enrichment Program Award and a Hanna H. Gray Fellowship from the Howard Hugues Medical Institute and was supported by an NIH NIAID T32 AI007151 and an NIAID F32 Al152296. This research was also supported by funding from the Chan Zuckerberg Initiative awarded to R.S.B. This project was supported by the North Carolina Policy Collaboratory at the University of North Carolina at Chapel Hill with funding from the North Carolina Coronavirus Relief Fund established and appropriated by the North Carolina General Assembly. This project was funded in part by the National Institute of Allergy and Infectious Diseases, NIH, U.S. Department of Health and Human Services award Al157155 (to R.S.B), U54 CA260543 (to R.S.B), Al149644 (to R.S.B), Al145687 (to P.A.), Al158571 (to B.F.H), as well as an animal models contract from the $\mathrm{NIH}$ (HHSN272201700036I). Funding was also supplied by the Intramural Research Program of the Vaccine Research Center, NIAID, NIH. This work was supported by a grant from the State of North Carolina with funds from the federal CARES Act, and by funds from NIH, NIAID, DAIDS grant Al142596 (to B.F.H). Animal histopathology services were performed by the Animal Histopathology \& Laboratory Medicine Core at the University of North Carolina, which is supported in part by an NCI Center Core Support Grant (5P30CA016086-41) to the UNC Lineberger Comprehensive Cancer Center. Part of this work was performed in the Duke Regional Biocontainment Laboratory, which received partial support for construction from the NIH/NIAD (UC6AI058607; to G.D.S) and with support from a cooperative agreement with DOD/DARPA (HR0011-17-2-0069; to G.D.S). This project was also supported by the North Carolina Policy Collaboratory at the University of North Carolina at Chapel Hill and Duke University with funding from the North Carolina Coronavirus Relief Fund established and appropriated by the North Carolina General Assembly. Cryo-EM data were collected on the Titan Krios system at the Shared Materials and Instrumentation Facility in Duke University. Author contributions: D.R.M., A.S., D.L., P.A., B.F.H., R.S.B conceived the study. D.R.M., A.S., S.G., D.L. designed experiments. D.R.M, A.S., S.G., D.L., G.D.C., R.P., M.B.,V.S., K.J., E.B., K.M., K.M., K.A., S.M., J.T., H.G. performed laboratory experiments. T.Z., P.D.K., B.S.G., and K.O.S provided critical reagents. D.R.M, A.S., S.G., D.L., G.D.LC., R.P., M.B., K.M., R.J.E., K.C., B.Y., K.A., S.M., J.T., H.G., S.S., T.Z., P.D.K., B.S.G., J.R.M., D.C.M, M.A., G.D.S., S.K., K.W., K.O.S., P.A., B.F.H., R.S.B. analyzed data and provided critical insight. D.R.M wrote the first draft of the paper. D.R.M, A.S., S.G., D.L., T.Z., P.D.K., B.S.G., J.R.M., D.C.M, M.A., G.D.S., K.W., K.O.S., P.A., B.F.H., R.S.B edited the paper. All authors reviewed and approved the manuscript. Competing interests: B.F.H, K.O.S., D.L., and G.D.S., are inventors on a U.S. patent (Coronavirus Antibodies and Uses Thereof. No. PCT/US2021/050552) filed on September 15, 2021, for mAb DH1047 and its applications described in this study. Data and materials availability: All data associated with this study are in the paper or supplementary materials. The structure of SARS-CoV-1 bound to DH1047 is available under the accession code PDB ID 7SG4 and the cryo-EM map under the code EMD-25105. Reagents developed in this study, including antibodies and viruses, will be made available to the scientific community by contacting R.S.B and B.F.H and completion of a materials transfer agreement. This work is licensed under a Creative Commons Attribution 4.0 International (CC BY 4.0) license, which permits unrestricted use, distribution, and reproduction in any medium, provided the original work is properly cited. To view a copy of this license, visit

https://creativecommons.org/licenses/by/4.0/. This license does not apply to figures/photos/artwork or other content included in the article that is credited to a third party; obtain authorization from the rights holder before using this material.

Submitted 31 May 2021

Accepted 19 October 2021

Published First Release 2 November 2021

10.1126/scitransImed.abl7125 
A
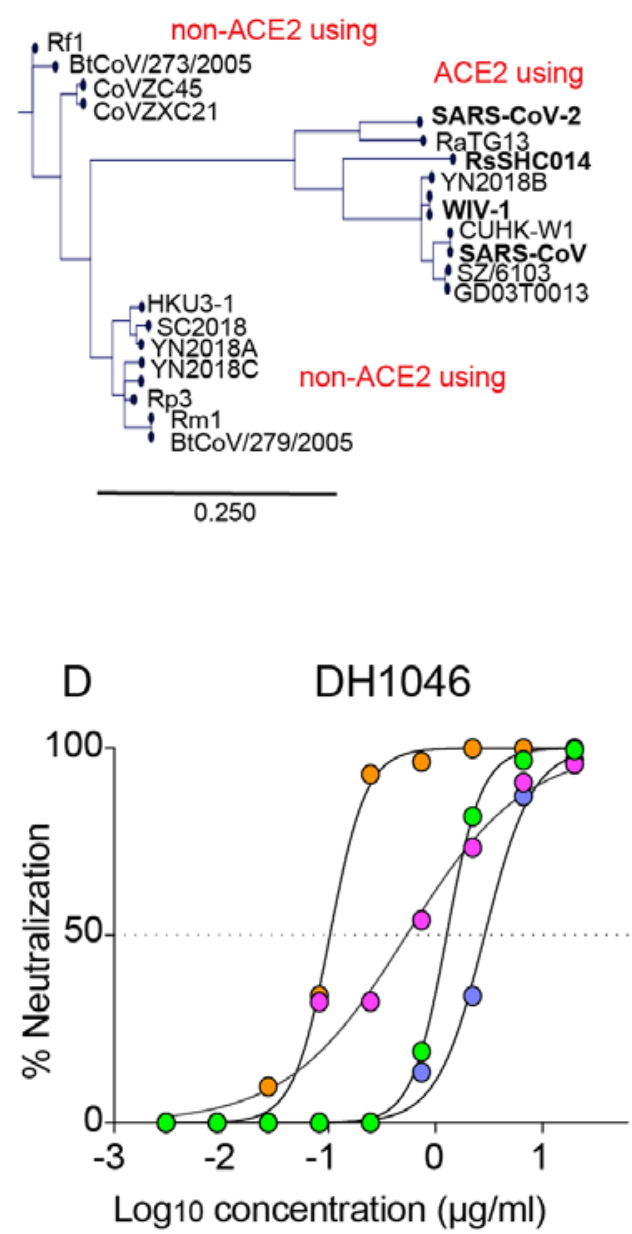

B

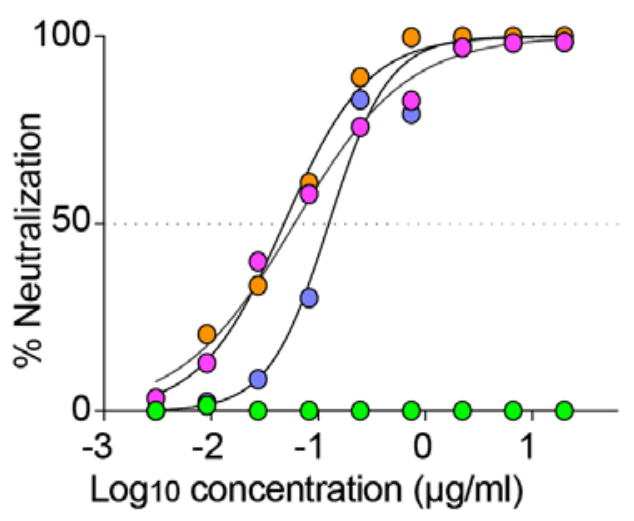

$\mathrm{E}$

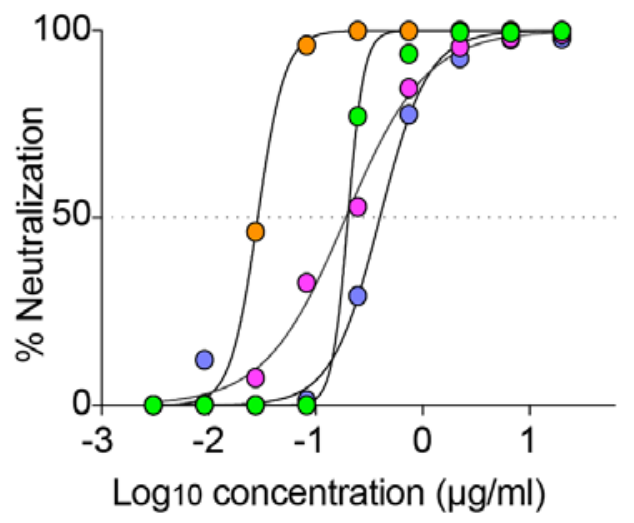

C $\quad \mathrm{DH} 1073$

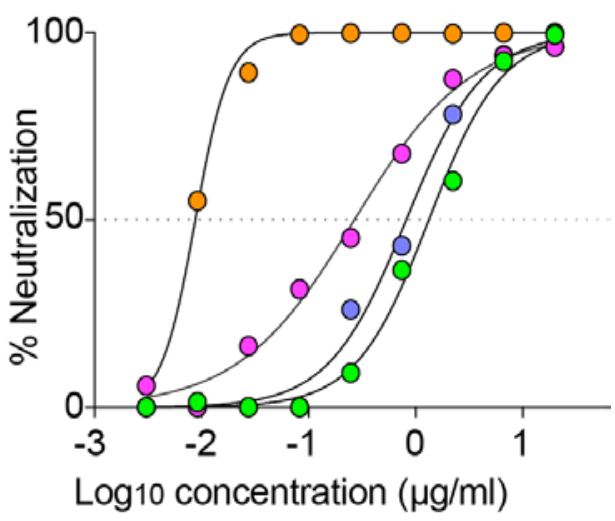

-SARS-CoV-2 MA

SARS-CoV

WIV-1

RsSHC014

Fig. 1. The identification of broadly neutralizing antibodies. (A) The genetic relationships of ACE2 and non-ACE2 using sarbecovirus receptor binding domains is shown. SARS-CoV-2 2AA MA is shown in purple, SARS-CoV is shown in orange, WIV-1 is shown in pink, and RsSHCO14 is shown in green. The scale bar indicates the genetic distance scale among sarbecoviruses of $25 \%$. The neutralization activity against sarbecoviruses is shown for DH1235 (B), DH1073 (C), DH1046 (D), and DH1047 (E). Data are representative of two technical replicates. 
Fig. 2. The binding breadth and structural determinants of broad neutralization. (A to D) The binding activity of cross-reactive antibodies was measured against SARS-CoV spike protein, SARS-CoV-2 spike protein, SARS-CoV-2 RBD, Pangolin GXP4L spike protein, RaTG13 spike protein, and RsSHCO14 spike protein. The antibodies tested were DH1235 (A), DH1073 (B), $\mathrm{DH} 1046$ (C), and $\mathrm{DH} 1047$ (D). (E) A cryo-EM reconstruction of $\mathrm{DH} 1047$ Fab bound to SARS-CoV spike protein is shown. Spike protein is shown in gray, with the underlying fitted model shown in cartoon representation. $\mathrm{DH} 1047$ is colored green and the RBD it is bound to is colored black, with the receptor binding motif within the RBD colored purple. An overlay of DH1047 bound to SARSCoV-1 and SARS-CoV-2 (PDB ID: 7LDI) spike proteins is shown in the middle panel. Overlay was performed with the respective RBDs. DH1047 bound to SARS-CoV and SARS-CoV-2 spike protein are shown in green and salmon, respectively. ACE2 (yellow surface representation, PDB $6 \mathrm{VW} 1$ ) binding to RBD is sterically hindered by $\mathrm{DH} 1047$. The views in panels $B$ and $C$ are related by a $180^{\circ}$ rotation about the vertical axis. (F) Sequence conservation within the DH1047 HCDR3 and LCDR3s is shown among 23 sarbecoviruses.
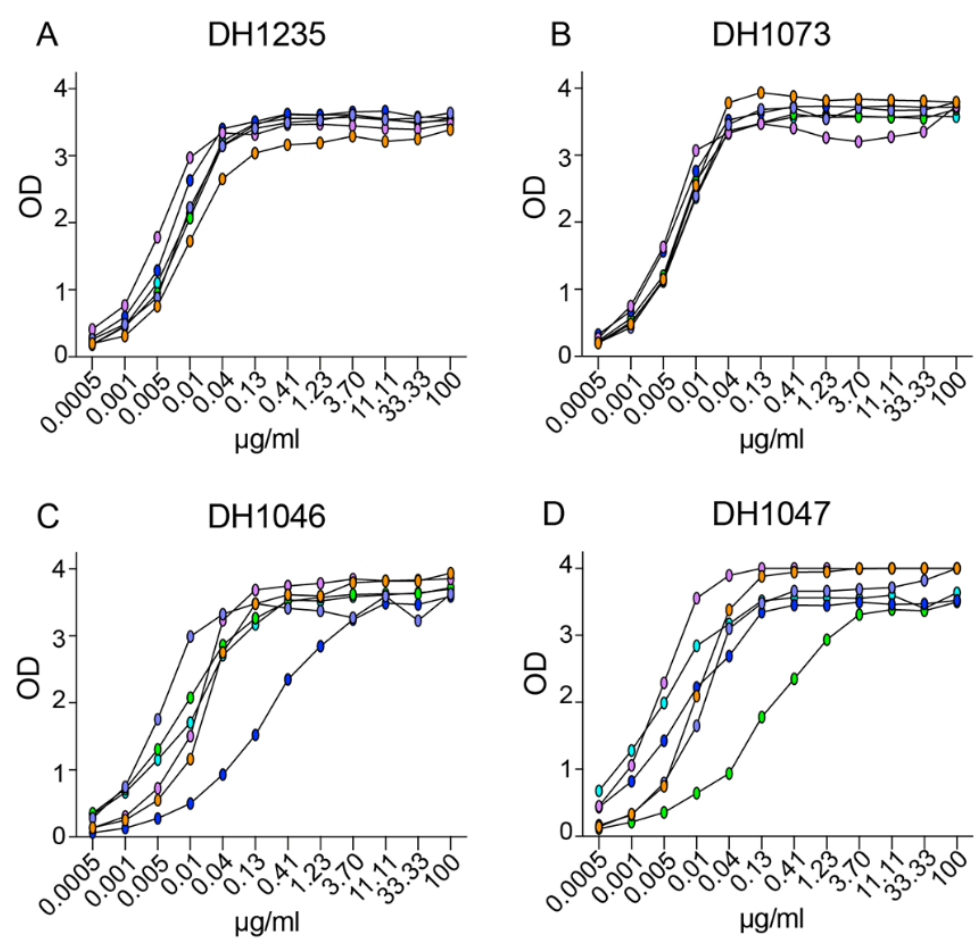

D $\quad$ DH1047

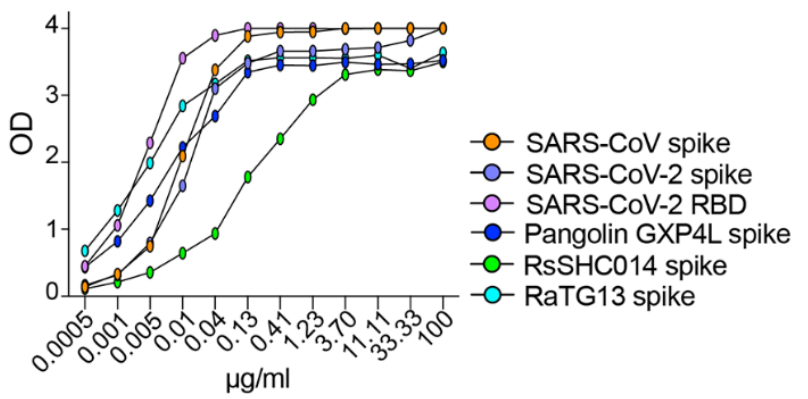

E

(bound to SARS-CoV spike)
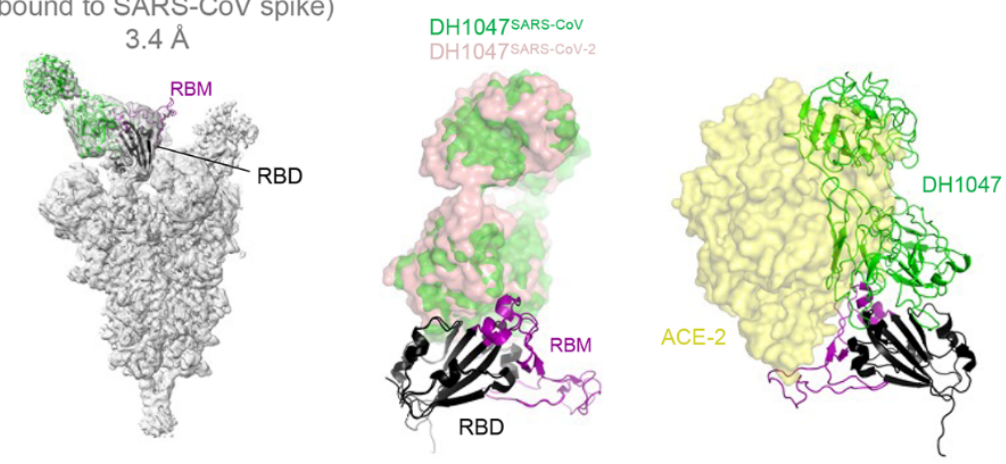

F DH1047 HCDR3 Sarbecovirus residues

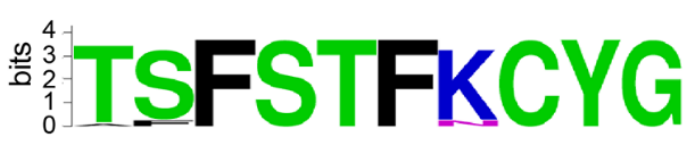

DH1047 LCDR3 Sarbecovirus residues

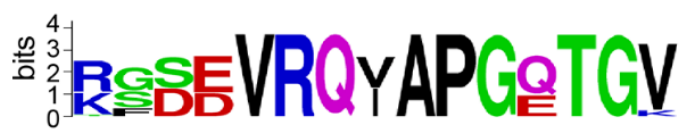


Fig. 3. Prevention and therapy of DH1047 against SARS-CoV in aged mice. (A) SARS-CoV mouse-adapted 15 (MA15) lung viral replication is shown. Mice $(n=5$ per group) treated 12 hours before infection with a control influenza mAb $\mathrm{CH} 65$ or one of the four broadly neutralizing antibodies DH1235, DH1073, DH1046, DH1047. Days post infection, dpi, limit of detection LoD; plaque forming units, PFU. (B) The percentage of starting weight is shown for mice ( $n=10$ per group) treated prophylactically (12 hours before infection) or therapeutically (12 hours after infection) with DH1047 or control and challenged with SARS-CoV MA15. Data are presented as mean \pm SEM. (C) Lung viral replication of SARSCoV MA15 is shown for mice treated prophylactically or therapeutically with $\mathrm{DH} 1047$ and control at 4 days post infection. (D) Macroscopic lung discoloration scores are shown for mice treated with $\mathrm{DH} 1047$ or control antibody prophylactically and therapeutically. (E) Lung pathology at day 4 post infection was measured by acute lung injury (ALI) scores in mice treated with $\mathrm{DH} 1047$ or control prophylactically
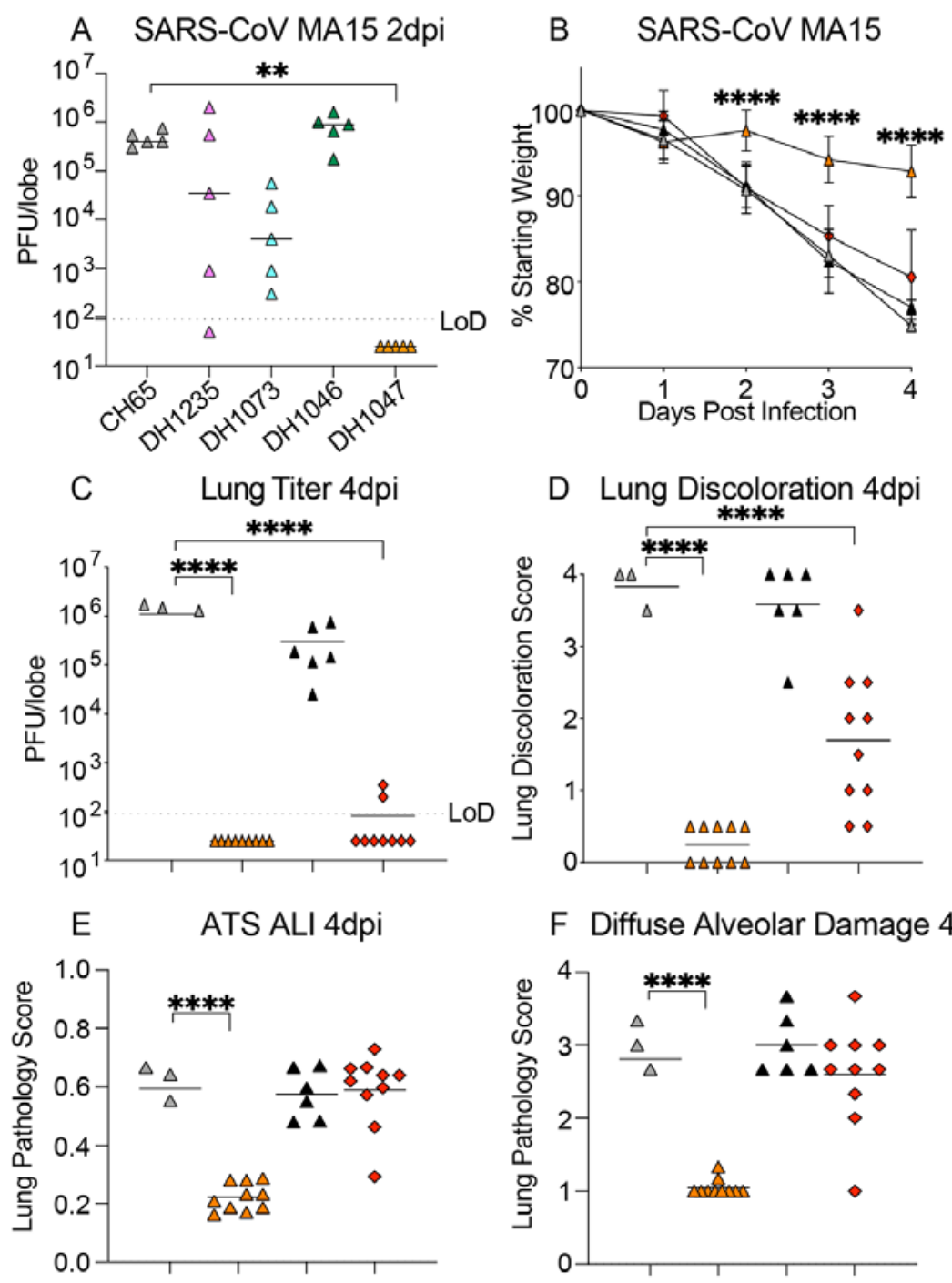

F Diffuse Alveolar Damage 4dpi


$\mathrm{H}$

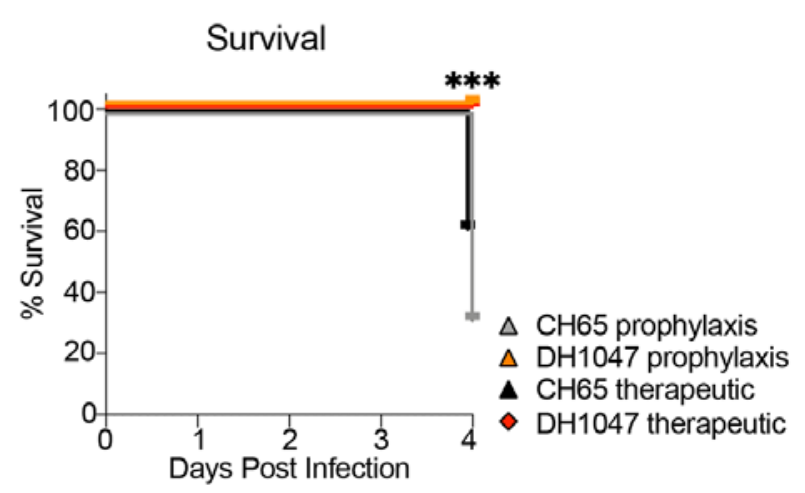

and therapeutically. (F) Lung pathology at day 4 post infection was measured by diffuse alveolar damage (DAD) in mice treated prophylactically and therapeutically with $\mathrm{DH} 1047$ and control. (G) Pulmonary function was measured by whole body plethysmography in mice treated with $\mathrm{DH} 1047$ or control mAb prophylactically or therapeutically. $(\mathrm{H})$ Percent survival is shown for mice treated with control or $\mathrm{DH} 1047$ prophylactically or therapeutically and challenged with SARS-CoV MA15. Horizontal bars in $(A)$ and ( $C$ to $G$ ) indicate mean. P-values shown in (B and $G$ ) were calculated using a two-way ANOVA followed by Tukey's multiple comparisons test. P-values are for $(A)$ and $(C$ to $E)$ were calculated using a one-way ANOVA followed by Dunnett's multiple comparisons. $P$ values for $(H)$ were calculated using a Mantel-Cox test. ${ }^{* *} p<0.01 ;{ }^{* *} p<0.001 ;{ }^{* * *} p<0.0001$. 

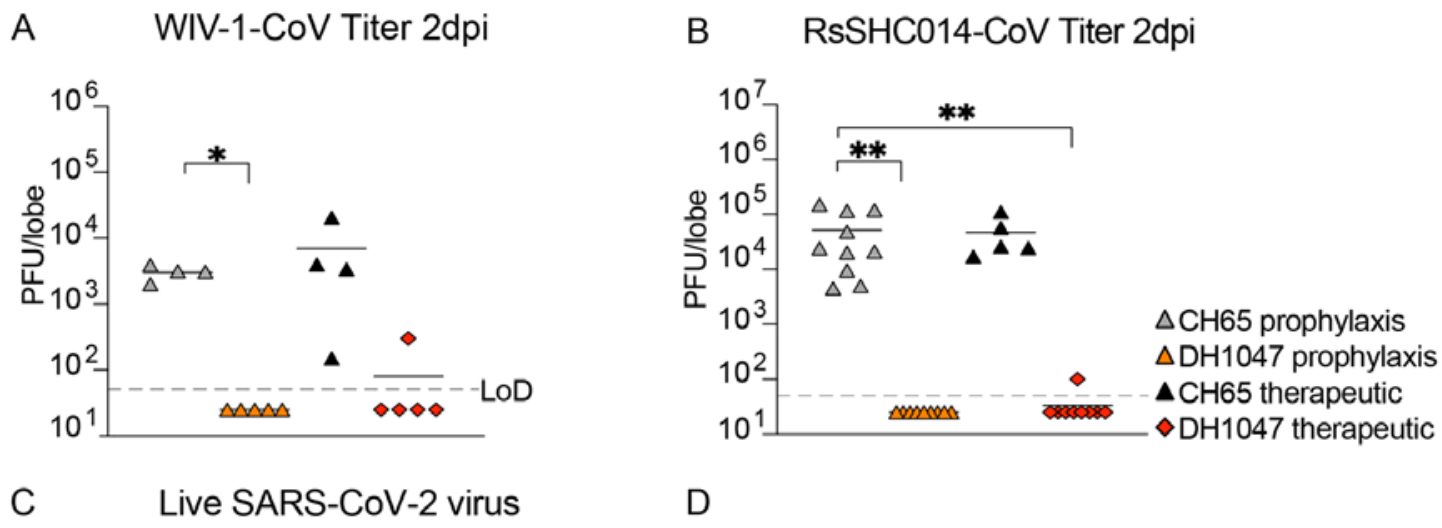

D

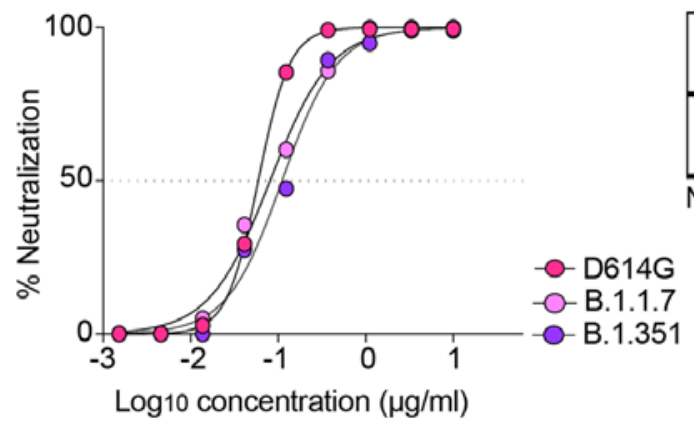

\begin{tabular}{|c|c|c|c|c|c|c|c|c|c|c|}
\hline \multirow{2}{*}{ mAb } & \multirow{2}{*}{ Assay } & D614G & B.1.1.7 & B.1.351 & P.1 & B.1.429 & B.1.526 & B.1.617.1 & B.1.617.2 \\
\cline { 3 - 11 } & & \multicolumn{8}{|c|}{ IC50 $(\mu \mathrm{g} / \mathrm{ml})$} \\
\hline \multirow{2}{*}{$\mathrm{DH} 1047$} & pseudovirus & 0.181 & 0.123 & 0.123 & 0.163 & 0.147 & 0.158 & 0.132 & 0.160 \\
\cline { 2 - 10 } & live virus & 0.059 & 0.081 & 0.111 & NT & NT & NT & NT & NT \\
\hline
\end{tabular}

NT: not tested

Fig. 4. Prophylactic and therapeutic activity of DH1047 against SARS-related bat coronaviruses and the in vitro neutralization against the SARS-CoV-2 variants. (A) Lung viral replication of WIV-1 is shown for mice ( $n=4$ to 5 per group) treated prophylactically or therapeutically with $\mathrm{DH} 1047$ or control at 2 days post infection. Horizontal bars indicate mean. (B) Lung viral replication of RsSHCO14 is shown for mice ( $\mathrm{n}=5$ to 10 per group) treated prophylactically or therapeutically with $\mathrm{DH} 1047$ or control at 2 days post infection. Horizontal bars indicate mean. (C) Live virus neutralization of SARS-CoV-2 D614G, B.1.1.7, and B.1.351 variants by $\mathrm{DH} 1047$ is shown. Data are representative of two technical replicates. (D) The comparison of the DH1047 neutralization activity against SARS-CoV-2 variants is shown for pseudovirus and live virus neutralization assays. NT, not tested. P-values in (A) and (B) were calculated using a oneway ANOVA followed by Dunnett's multiple comparisons test. ${ }^{*} p<0.05$; ${ }^{* *} p<0.01$. 
A SARS-CoV-2 B.1.351 B SARS-CoV-2 B.1.351 Titer 4dpi C Lung Discoloration 4dpi


D ATS ALI 4dpi

E Diffuse Alveolar Damage 4dpi

F Survival
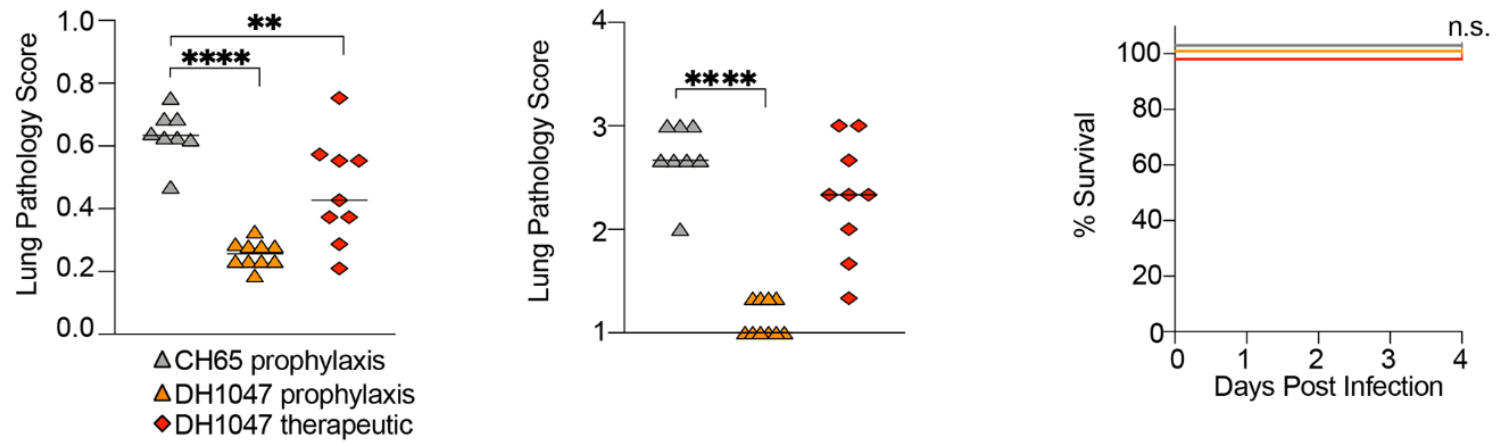

G SARS-CoV-2 B.1.351

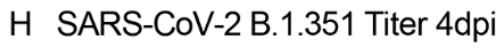

I Lung Discoloration 4dpi
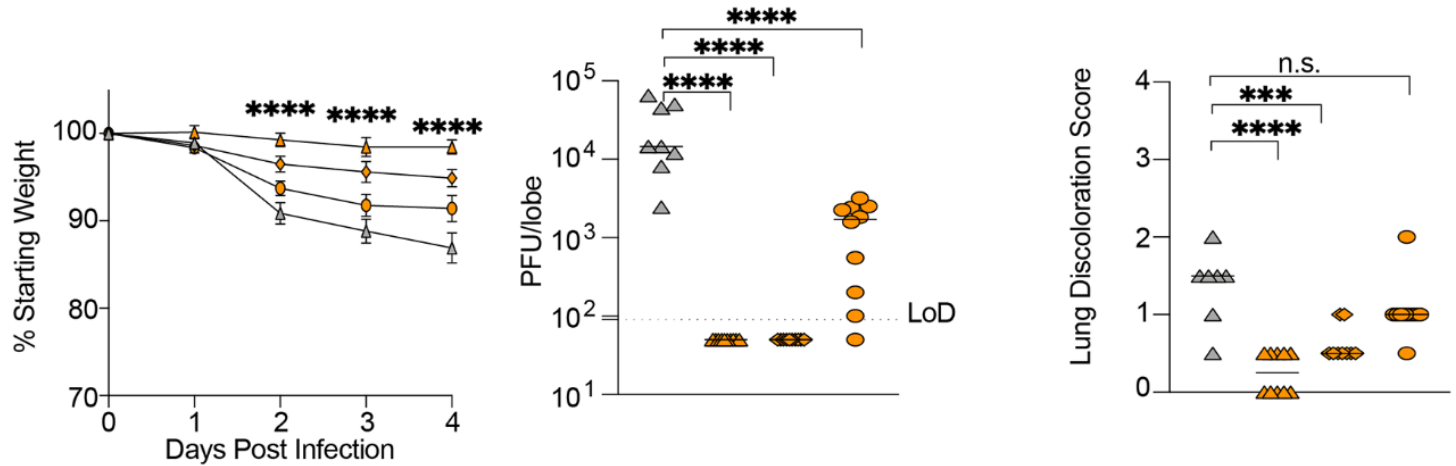

$\triangle \mathrm{DH} 1047,10 \mathrm{mg} / \mathrm{kg}$

$\diamond \mathrm{DH} 1047,5 \mathrm{mg} / \mathrm{kg}$

O DH1047, $1 \mathrm{mg} / \mathrm{kg}$

$\triangle \mathrm{CH} 065,10 \mathrm{mg} / \mathrm{kg}$

$J$
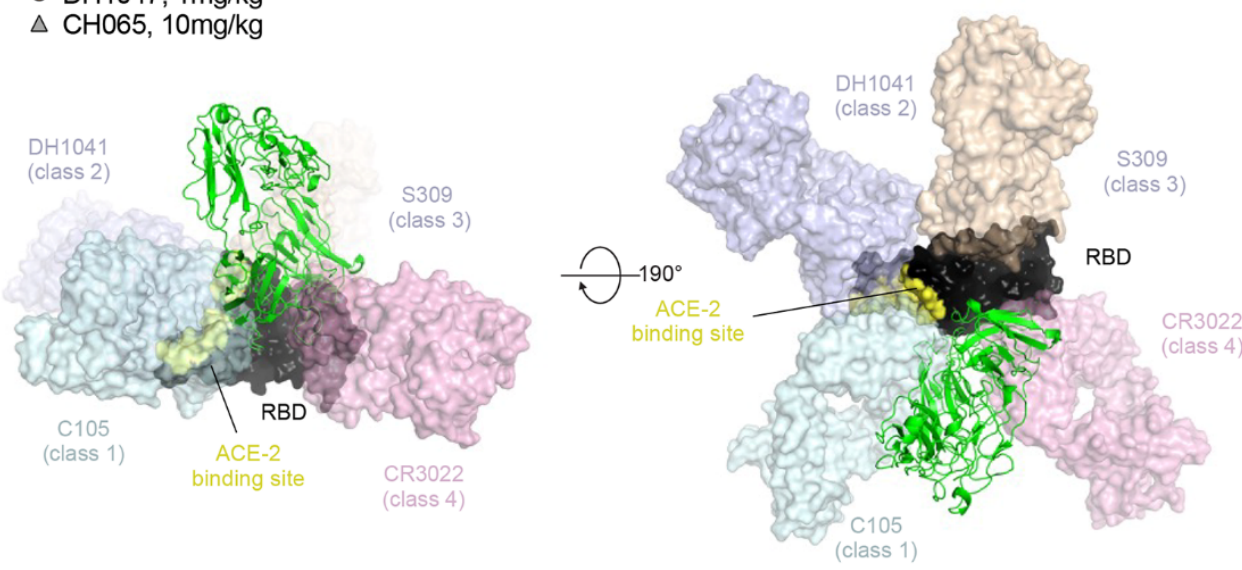
Fig. 5. Prophylaxis and therapy of DH1047 against SARS-CoV-2 B.1.351 in mice. (A) Percent of starting weight is shown for mice ( $n=10$ per group) treated prophylactically (12 hours before infection) or therapeutically (12 hours after infection) with $\mathrm{DH} 1047$ or control antibody and challenged with SARS-CoV-2 B.1.351. (B) Lung viral replication is shown at 4 days post infection for mice infected with SARS-CoV-2 B.1.351 and treated prophylactically or therapeutically with $\mathrm{DH} 1047$ or control. (C) Macroscopic lung discoloration scores are shown at 4 days post infection for mice infected with SARSCoV-2 B.1.351 and treated prophylactically or therapeutically with $\mathrm{DH} 1047$ or control. (D) Lung pathology measured by acute lung injury (ALI) scores is shown at 4 days post infection for mice infected with SARS-CoV-2 B.1.351 and treated prophylactically or therapeutically with $\mathrm{DH} 1047$ or control. (E) Lung pathology measured by diffuse alveolar damage (DAD) is shown at 4 days post infection for mice infected with SARS-CoV-2 B.1.351 and treated prophylactically or therapeutically with $\mathrm{DH} 1047$ or control. (F) Percent survival is shown for SARS-CoV-2 B.1.351-infected mice treated with $\mathrm{DH} 1047$ prophylactically or therapeutically with $\mathrm{DH} 1047$ or control. (G) Percent of starting weight is shown for mice ( $n=10$ per group) treated prophylactically with $\mathrm{DH} 1047$ (12 hours before infection) at de-escalating doses of 10,5 , and $1 \mathrm{mg} / \mathrm{kg}$ or with $10 \mathrm{mg} / \mathrm{kg}$ control mAb, CHO65. (H) Lung viral titers in control and DH1047-treated mice at 10, 5, and 1mg/kg. (I) Lung discoloration in control and DH1047treated mice at the various $m A b$ doses. Data in ( $A$ and $G$ ) are presented as mean \pm SEM. Horizontal bars in ( $B$ to $E)$ and $(H$ and $I$ ) represent mean. P-values shown in ( $A$ and $G$ ) are from a two-way ANOVA followed by Tukey's multiple comparisons test, and P-values shown in ( $B$ to $E$ ) and ( $H$ and $I$ ) are from a one-way ANOVA followed by Dunnett's multiple comparisons test. Differences in survival were measured by a Mantel-Cox test. ${ }^{* *} \mathrm{p}<0.01$; ${ }^{* *} \mathrm{p}<0.001$; ${ }^{* * *} \mathrm{p}<0.001$; ns, not significant. (J) DH1047 binding is shown relative to binding of other known antibody classes that bind the RBD. RBD is shown in black with the ACE2 footprint on the RBD colored yellow. DH1047 is shown in cartoon representation and colored green. The other antibodies are shown as transparent surfaces: C105 (pale cyan, Class 1, PDB ID: 6XCN and 6XCA), DH1041 (light blue, Class 2, PDB ID: 7LAA), S309 (wheat, Class 3, PDB ID:6WS6 and 6WPT) and CR3022 (pink, Class 4, PDB ID: 6YLA) 